\title{
Implicações hidrogeomorfológicas do rompimento da barragem de rejeito da Mina do Córrego do Feijão - MG
}

\author{
Hydrogeomorphological impacts of the Córrego do Feijão iron tailings dam break - Minas \\ Gerais state, Brazil
}

\author{
Regina Paula Benedetto de Carvalho \\ Pesquisadora pós-doutora em Geomorfologia e Recursos Hídricos, IGC/UFMG, Brasil \\ reginapaulabenedettodec@gmail.com \\ Antônio Pereira Magalhães Jr. \\ Professor Titular do Departamento de Geografia da UFMG, Brasil \\ antonio.magalhaes.ufmg@gmail.com \\ Luiz Fernando de Paula Barros \\ Professor Adjunto do Departamento de Geografia da UFMG, Brasil \\ luizfpaulabarros@gmail.com
}

\begin{abstract}
Resumo
O artigo busca identificar e analisar alterações hidrogeomorfológicas nos fundos dos vales do ribeirão Ferro-Carvão e do rio Paraopeba decorrentes do rompimento da barragem de rejeito B1 da Mina do Córrego do Feijão (Brumadinho-MG). A pesquisa se baseou no uso de imagens de satélite e de dados quali-quantitativos da primeira estação chuvosa pós-rompimento. $\mathrm{O}$ conjunto das alterações identificadas permitiu a definição de cinco trechos fluviais, estando a abrangência dos impactos morfológicos diretamente relacionada à proximidade com o local do rompimento, fato que não se verifica, necessariamente, com relação aos aspectos hidrossedimentológicos. Enquanto o Trecho 1 foi marcado pelo completo soterramento do fundo do vale, nos demais a formação de depósitos de rejeito nas margens, o surgimento de barras de canal na calha do Paraopeba e o entulhamento de áreas de confluência até o reservatório de Retiro Baixo são indicativos de consequências importantes do desastre. O trabalho ilustra como os eventos de rompimento de barragens de rejeito tendem a comprometer a configuração e a dinâmica hidrogeomorfológica de sistemas fluviais, além dos conhecidos impactos socioambientais.
\end{abstract}

Palavras-chave: Impactos Hidrogeomorfológicos; Bacia do Rio Paraopeba; Sistemas Fluviais; Rompimento de Barragem de Rejeito.

\begin{abstract}
The paper aims to identify and analyze hydrogeomorphological changes in the Ferro-Carvão and Paraopeba bottom valleys due to the rupture of the Córrego do Feijão iron tailings dam Minas Gerais, Brazil. The research was based on satellite images and quali-quantitative data from the first postrupture rainy season. The set of changes allowed the definition of five river sections. The extent of the morphological impacts is directly related to the dam proximity, which does not necessarily occur concerning hydrosedimentological aspects. While in Section 1, the Ferro-Carvão bottom valley was completely buried. The tailings deposits on the margins, the channel bars in the Paraopeba, the tailings accumulation in the confluence areas, and the Retiro Baixo water dam indicate the disaster. The work illustrates how tailing dam rupture events tend to compromise the morphological configuration and hydrogeomorphological dynamics of river systems, in addition to the well-known socioenvironmental impacts.
\end{abstract}

Keywords: Hhydrogeomorphological Impacts; Paraopeba River Basin; Fluvial Systems; Iron Tailing Dam Failure. 


\section{INTROUÇÃO}

No período mais recente do tempo geológico, o ser humano se tornou um importante agente geomorfológico na transformação da superfície terrestre, alterando a morfologia e a morfodinâmica de sistemas naturais a partir de processos de ocupação e atividades econômicas como a agropecuária e a mineração (GOUDIE, 1993; HOOKE, 2000; OLIVEIRA; PELOGGIA, 2014). O termo Tecnógeno é usado para se referir a esse contexto geológico-geomorfológico atual (PELOGGIA, 2005), marcando, portanto, um período de transformações generalizadas dos sistemas hidrogeomorfológicos (particularmente nos fundos de vales), fazendo com que a noção de ambientes “naturais" seja aplicada e adaptada a poucas realidades do Planeta. Nesse sentido, os depósitos tecnogênicos são aqueles correlativos da ação geológica humana e representam eventos de caráter novo e independente e, portanto, distintos da processualidade holocênica precedente (PELOGGIA, 2005).

As pesquisas sobre o Tecnógeno têm um desenvolvimento crescente no Brasil e envolvem, principalmente, ambientes fluviais, áreas de mineração e áreas urbanas (FRANÇA JUNIOR; SOUZA, 2014). As alterações antrópicas se tornam ainda mais proeminentes em casos de tragédias ambientais com impactos intensos, como no caso de rompimentos de barragens. Os rompimentos de barragens de rejeito são exemplos emblemáticos da capacidade humana de impactar de modo significativo, e muitas vezes definitivo, os sistemas hidrogeomorfológicos, tendo se tornado recorrentes em escala nacional e internacional a partir do Século XX (REIS et al., 2020).

Particularmente nos anos 2010, o estado de Minas Gerais foi palco de importantes tragédias socioambientais envolvendo rupturas de barragens no Quadrilátero Ferrífero (COTA et al., 2019). Em 05 de novembro de 2015, no município de Mariana, ocorreu a ruptura da barragem de Fundão, que ejetou cerca de 60 bilhões de litros de rejeito de minério liquefeito na bacia do rio Doce (MILANEZ; LOSEKANN, 2016), causando a morte de 19 pessoas e afetando uma cadeia de artérias hidrográficas até a foz, no litoral do estado do Espírito Santo. Dentre os impactos socioambientais, a tragédia causou alterações geomorfológicas que romperam a dinâmica até então vigente, com destaque para os fundos dos vales dos rios Gualaxo do Norte e do Carmo, afluentes do rio Doce (MENDES; FELIPPE, 2019).

Outra tragédia ocorreu no dia 25 de janeiro de 2019, quando houve o rompimento da barragem de rejeito de minério de ferro B1, da Mina Córrego do Feijão, no município de Brumadinho. O evento causou a morte de mais de 270 pessoas, incluindo trabalhadores da mina, moradores da região e turistas, sendo que algumas ainda não foram encontradas (INSTITUTO GUAICUY, 2020).

A barragem B1 foi construída em 1976 pela Ferteco Mining Company e manteve-se em operação até 2016 sob a responsabilidade da mineradora Vale S.A., sendo destinada à contenção de 
rejeito de minério de ferro. A composição dos rejeitos de minério de ferro inclui grãos de formas, tamanhos e pesos variados, principalmente de hematitas e quartzo (ESPÓSITO, 2000). A estrutura da barragem possuía $86 \mathrm{~m}$ de altura, $720 \mathrm{~m}$ de comprimento de crista e área de cerca de $250.000 \mathrm{~m}^{2}$ (CPRM, 2019a), possuindo, até a data do rompimento, cerca de 12 milhões de metros cúbicos $\left(\mathrm{Mm}^{3}\right)$ de rejeito (IGAM, 2020b). Após sucessivos alteamentos, pelo método de montante, ao longo do tempo, o rejeito foi sendo depositado em camadas e de modo hidraulicamente heterogêneo, "ora lançando-se rejeitos em praias, ora lançando-se os rejeitos submersos, resultando em compacidades muito heterogêneas, entre materiais fofos a compactos" (MSPJ, 2019 p.78) que induzem a condições de excesso de poropressão (MJSP, 2019).

Nos instantes seguintes à ruptura da barragem B1, uma quantidade expressiva de rejeito devastou toda a estrutura administrativa da mineradora Vale S.A., atingindo comunidades, propriedades e outras estruturas que se situavam no vale do ribeirão Ferro-Carvão, até alcançar o rio Paraopeba. Após o rompimento, cerca de $2 \mathrm{Mm}^{3}$ de rejeito continuam retidos na $\mathrm{B} 1$, enquanto 7,8 $\mathrm{Mm}^{3}$ se espalharam e soterraram o fundo do vale do ribeirão Ferro-Carvão até a confluência com o rio Paraopeba e 2,2 $\mathrm{Mm}^{3}$ foram carreados pelos fluxos para jusante (IGAM, 2020b). Ao longo do tempo, o rejeito continuou sendo mobilizado pelo ribeirão Ferro-Carvão em direção ao rio Paraopeba, impactando de maneira gradativa e permanente a dinâmica fluvial e a qualidade da água e dos solos na bacia (INSTITUTO GUAICUY, 2020). Os impactos se estenderam ao longo do rio Paraopeba e atingiram os reservatórios de Retiro Baixo e Três Marias, gerando danos ainda por estimar aos ecossistemas e comunidades.

A fim de contribuir com a compreensão das consequências do desastre, este artigo busca identificar e analisar alterações hidrogeomorfológicas nos sistemas fluviais nos fundos dos vales do ribeirão Ferro-Carvão e do rio Paraopeba que tenham ocorrido após o rompimento da barragem B1 da Mina do Córrego do Feijão. Este foco busca sinalizar, particularmente, possíveis impactos no padrão morfológico dos cursos d'água e em feições deposicionais presentes na área. De modo complementar, pretendeu-se analisar evidências de alterações no comportamento hidrossedimentológico da bacia do rio Paraopeba durante a primeira estação chuvosa após o rompimento, envolvendo parâmetros quantitativos e qualitativos de análise de água e sedimentos.

\section{PROCEDIMENTOS METODOLÓGICOS}

O trabalho partiu do levantamento de bibliografias (publicações oficiais, teses e artigos científicos) direcionadas à caracterização dos aspectos físico-naturais e ambientais da bacia do rio Paraopeba, com ênfase na geologia, geomorfologia, hidrografia e clima da bacia. Em seguida foi feita a identificação de alterações na morfologia dos fundos dos vales do ribeirão Ferro-Carvão e do rio 
Paraopeba, por meio da comparação e vetorização manual de feições fluviais. Para tanto, foram utilizadas imagens de satélite disponíveis no software Google Earth Pro, abrangendo o período do início ao final do período chuvoso no qual ocorreu o rompimento da barragem B1 da Mina do Córrego do Feijão (Tabela 1). De acordo com IGAM (2020a), o período de chuvas na bacia do rio Paraopeba ocorre de outubro a abril, sendo a totalidade desses meses considerados na análise das imagens utilizadas.

Nesse sentido, realizou-se a sobreposição de dados vetoriais sobre as imagens de satélite para se construir uma base de dados georreferenciada para a área de estudo. Tendo em vista que a rede de drenagem da sub-bacia do ribeirão Ferro-Carvão não é visualizada nas imagens, foi necessário gerar um dado vetorial com a tendência das rotas dos fluxos superficiais, o qual balizou a análise dos vales fluviais e as mudanças observadas a partir da data do rompimento da barragem ( 25 de janeiro de 2019). Devido às limitações escalares dos Modelos Digitais de Terreno (MDT) disponíveis, para a elaboração do perfil longitudinal da rota do rejeito foram utilizados dados de cartas topográficas do IBGE nas escalas de 1:50.000 e 1:100.000 (baixo curso), as quais apresentam curvas de nível equidistantes em 20 e $50 \mathrm{~m}$, respectivamente. Além do perfil longitudinal, foram calculados outros dados e parâmetros morfométricos para subsidiar as análises: extensão dos canais, amplitude altimétrica, índice de sinuosidade (HORTON, 1945) e gradiente do canal (CHRISTOFOLETTI, 1980).

Considerando que as feições fluviais refletem a dinâmica dos cursos d'água ao longo do tempo e suas tendências de erosão ou deposição sedimentar, as alterações das formas foram adotadas como indicadores de impactos do rompimento da barragem no sistema fluvial. No tocante à morfologia de cursos d'água, de fundos de vales, de feições deposicionais e de outros sistemas hidrogeomorfológicos (como áreas úmidas), a pesquisa foi ancorada na associação de bases teóricas e conceituais, bem como em critérios e abordagens de sistemas fluviais propostos na literatura (BRIERLEY; FRYIRS, 2005; CHRISTOFOLETTI, 1981; GOMES; MAGALHÃES JÚNIOR, 2018; MAGALHÃES JÚNIOR; BARROS, 2020; ROSGEN, 1994; SUMMERFIELD, 1991).

De modo complementar à identificação das alterações morfológicas, foram analisados dados sobre a composição química e física do rejeito e seu comportamento mediante a deflagração do rompimento da barragem para caracterização das alterações na planície do ribeirão Ferro-Carvão (VERGILIO et al., 2020; MJSP - MG 2019). Para análise do rio Paraopeba, foram utilizados dados de hidrossedimentologia e qualidade da água coletados até a primeira estação chuvosa pósrompimento. Para isso, foram consultados, principalmente, o banco de dados e os boletins oficiais sobre o rompimento (publicados pelo Ministério da Saúde, Serviço Geológico Brasileiro - CPRM e Instituto Mineiro de Gestão das Águas - IGAM), além de artigos em periódicos científicos. 
Para análise dos sedimentos fluviais e da qualidade da água do rio Paraopeba foram utilizados dados e informações de diferentes locais entre a Estação Alberto Flores (EAF) e o barramento de Retiro Baixo. As análises envolveram dados históricos do CPRM (de 2002 a 2018) e do monitoramento especial realizado entre 26/01 e 31/05/2019, abrangendo parâmetros de águas e sedimentos, a saber: turbidez da água, vazão (descarga líquida), descarga sólida, granulometria e concentrações de sedimentos de fundo, sedimentos em suspensão e sedimentos totais, embora nem todos os pontos de amostragem possuam dados sobre os mesmos parâmetros. Foram contemplados dados das seguintes estações (CPRM, 2019; 2019a): Alberto Flores (EAF), Mário Campos (EMC), Ponte Nova do Paraopeba (EPNP), Ponte da Taquara (EPT), Ponte MG-420 (EP420) e Montante Retiro Baixo (EMRB).

Em relação ao IGAM, foram utilizados dados complementares de estações situadas no Paraopeba com maior período e frequência de monitoramento, quais sejam, as estações BP070 (São João de Bicas, município de Betim) e BP082 (localidade de São José da Varginha, município de Esmeraldas). O período considerado foi de 1997 até 2018, e este foi comparado ao período após o rompimento, a partir do dia 26/01/2019 até final de abril (29/04/2019). Em termos de qualidade da água, foram analisados dados de sólidos totais e a cor verdadeira (IGAM, 2020) ${ }^{1}$.

Os limites normativos para turbidez, sólidos suspensos e cor verdadeira seguem os padrões previstos para corpos d'água de Classe 2, conforme a Deliberação Normativa do COPAM/CERH $\mathrm{N}^{\circ} 01 / 2008$. Os demais parâmetros adotados e monitorados pelo CPRM ou pelo IGAM não possuem limites legais para esta classe. No caso da cor da água, além das análises amostradas pelo IGAM (cor verdadeira), foram feitas interpretações visuais, por meio de imagens, contribuindo para comparações entre aspectos da água antes e após o rompimento da barragem.

A tabela 1 sintetiza as categorias de dados e informações adotadas na pesquisa.

Tabela 1: Categorias de dados/informações utilizadas na pesquisa.

\begin{tabular}{lccll}
\hline Trecho fluvial & \multicolumn{2}{c}{$\begin{array}{c}\text { Análise de imagens de } \\
\text { satélite (datas) }\end{array}$} & \multicolumn{2}{c}{ Dados e informações do rejeito, água e sedimentos } \\
& $\begin{array}{c}\text { Pré- } \\
\text { rompimento }\end{array}$ & $\begin{array}{c}\text { Pós- } \\
\text { rompimento }\end{array}$ & Fontes & $\begin{array}{c}\text { Pontos de amostragens e estações de } \\
\text { monitoramentos }\end{array}$ \\
\hline $\begin{array}{l}\text { Ribeirão Ferro- } \\
\text { Carvão }\end{array}$ & $14 / 12 / 2018$ & $29 / 03 / 2019$ & $\begin{array}{l}\text { MJSP - } \\
\text { MG }\end{array}$ & $\begin{array}{l}\text { Comportamento do rejeito (uso de dados } \\
\text { bibliográficos e modelados) }\end{array}$
\end{tabular}

\footnotetext{
${ }^{1}$ Uma análise prévia dos Sólidos Totais Dissolvidos mostrou que não há diferença significativa de valores nos cenários anterior e posterior ao rompimento. Portanto, foi selecionado o parâmetro Sólidos Totais.
} 


$\begin{array}{ll}\begin{array}{l}\text { Ministéri } \\ \text { o da }\end{array} & \begin{array}{l}10 \text { amostras de rejeito coletadas (pelo } \\ \text { corpo de bombeiros) ao longo da planície } \\ \text { do ribeirão Ferro-Carvão, do local da } \\ \text { barragem até a foz. }\end{array} \\ \begin{array}{l}\text { Vergilio } \\ \text { et al. }\end{array} & \begin{array}{l}1 \text { amostra de rejeito coletada próximo à } \\ (2020)\end{array} \\ \text { foz do ribeirão Ferro-Carvão }\end{array}$

Rio Paraopeba a partir da estação Alberto Flores (CPRM) até o barramento de Retiro Baixo

$\begin{array}{cccc} & 28 / 012019, & & \\ & 08 / 03 / 2019, & \text { CPRM } & \text { Dados das estações EAF, EMC, EPNP*, } \\ \text { EPT, EP420 e EMRB } \\ 14 / 12 / 2018 \text { e } & 14 / 03 / 2019, & & \\ 14 / 10 / 2018 & 24 / 03 / 2019, & & \\ 29 / 03 / 2019 \text { e } & \text { IGAM } & \text { Dados das estações BP070 e BP082 } \\ 29 / 04 / 2019 & & \end{array}$

*Estação instalada após a data do rompimento.

A integração das informações morfológicas e hidrossedimentométricas permitiu a compartimentação da área de estudo em trechos fluviais conforme as tendências de alterações apresentadas. Os tipos de alterações em cada trecho foram ilustrados por recortes dos vales fluviais a partir da confecção de croquis representativos das condições geomorfológicas locais antes e após o rompimento da barragem.

\section{3. ÁREA DE ESTUDO}

A área investigada foi delimitada a partir da barragem B1 da Mina do Córrego de Feijão, na sub-bacia do ribeirão Ferro-Carvão (Fig.1). O ribeirão possui bacia com área de $32,8 \mathrm{~km}^{2}$ e vazão média de cerca de 600 L/s (CPRM, 2019a). A área estudada abrange todo o vale do Ferro-Carvão até a sua foz no rio Paraopeba, estendendo-se, para montante, até a estação de monitoramento fluviométrico de Alberto Flores (EAF), no município de Brumadinho (a montante da confluência) e, para jusante, até o barramento do reservatório da Usina de Retiro Baixo, entre os municípios de Curvelo e Pompéu, no baixo Paraopeba. Esse reservatório atua como nível de base regional e foi criado para geração de energia elétrica ( $82 \mathrm{MW})$, possuindo área inundada de $22,58 \mathrm{~km}^{2}$, cota máxima de inundação em 616 m e volume útil de $241.590 \mathrm{~m}^{3}$ (FURNAS, 2020). 

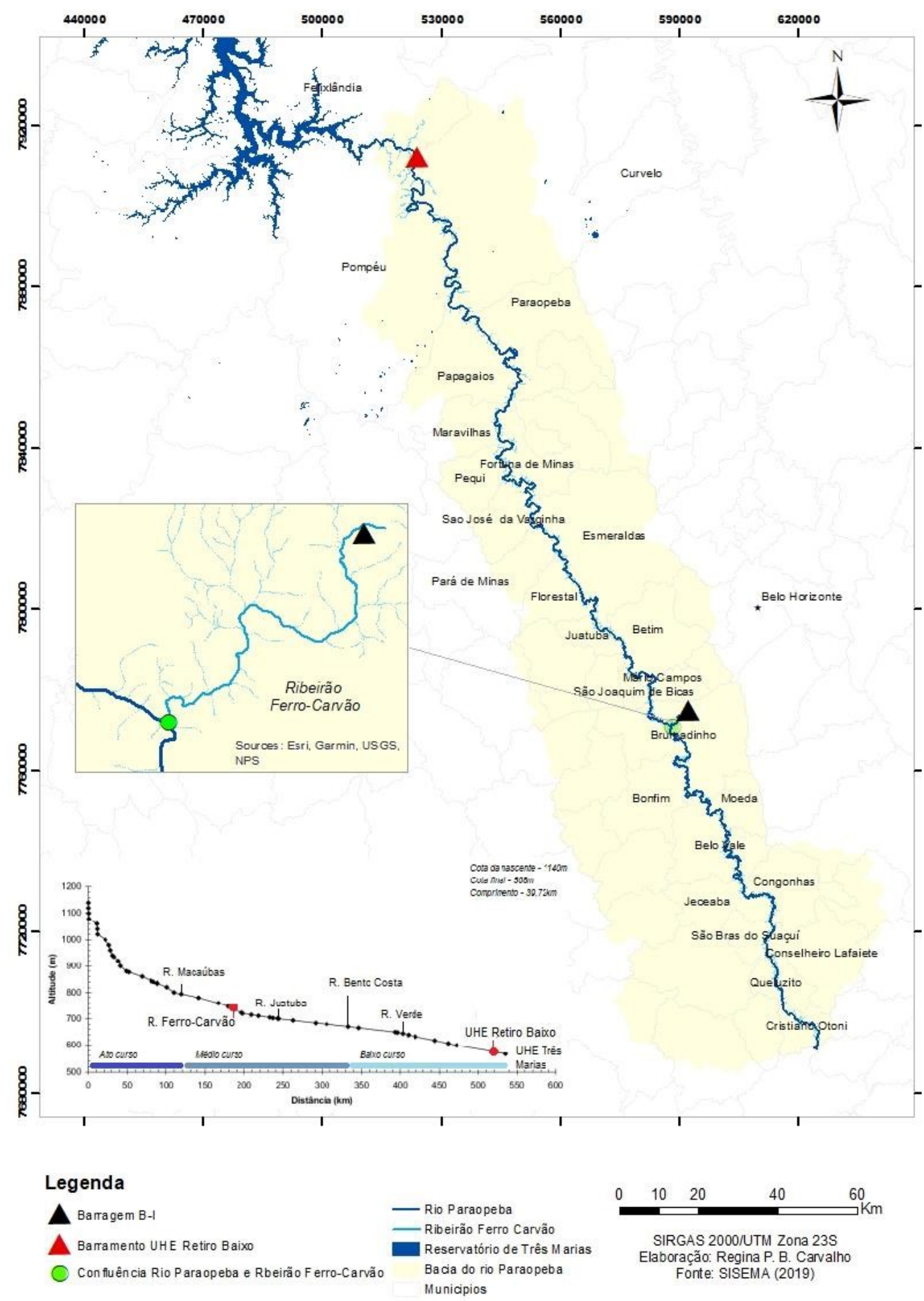

Figura 1 - Área de estudo e perfil longitudinal do rio Paraopeba.

Fonte: Adaptado de Medeiros (2000).

O rio Paraopeba é afluente da margem direita do rio São Francisco e a sua bacia se localiza na região central de Minas Gerais, na mesorregião Metropolitana de Belo Horizonte (IGAM, 2020c). As suas nascentes estão no município de Cristiano Otoni, a uma altitude de cerca de $1.140 \mathrm{~m}$, e o rio se estende por cerca de $370 \mathrm{~km}$, no sentido geral SE-NW, até a foz no reservatório da Usina de Três Marias. A bacia possui área de $13.640 \mathrm{~km}^{2}$ e os principais afluentes são os rios Maranhão, Camapuã, 
Macaúbas, Manso e Soledade (CPRM, 2019a). Os cursos d'água possuem padrão geral sinuoso, com trechos meandrantes concentrados nas áreas mais suavizadas.

O clima regional é típico de zonas tropicais quentes e úmidas, com elevada radiação solar e pluviosidade, bem como marcada sazonalidade (COBRAPE, 2018). O período chuvoso ocorre de outubro a abril, com maiores valores acumulados entre novembro e janeiro (IGAM, 2020a). As chuvas no primeiro trimestre do ano costumam registrar valores entre $500 \mathrm{~mm}$ e $650 \mathrm{~mm}$, no entanto, 2019 apresentou uma média inferior nesse período, entre $380 \mathrm{~mm}$ e $612 \mathrm{~mm}$, com um cenário anômalo de janeiro mais seco e fevereiro mais chuvoso (IGAM, 2020a).

A bacia do Paraopeba abrange os Planaltos de Oliveira e Campos das Vertentes, as Depressões do Alto e Médio São Francisco, o Patamar de Belo Horizonte, a Serra do Quadrilátero Ferrífero e a Serrania de Pará de Minas (IBGE, 2010). Na bacia do alto e médio curso, predominam rochas meso e neoarqueanas do Embasamento Cristalino (EC) e do Supergrupo Rio das Velhas (SGRV), além das proterozoicas do Supergrupo Minas (SGM). Por sua vez, entre o médio e o baixo cursos predominam rochas neoproterozóicas da Bacia Intracratônica do São Francisco, relacionadas ao Grupo Bambuí - GB. O EC é formado principalmente por rochas graníticas, gnaisses e migmatitos que condicionam um relevo de serras e planaltos em zonas de interflúvios, onde há maior densidade da drenagem (CHAVES, 2011; CARVALHO et al., 2019). As rochas do SGM ocupam faixas perpendiculares ao curso principal, particularmente com itabiritos e quartzitos que condicionam a gênese de formações serranas residuais nas bordas do Quadrilátero Ferrífero (QF). Nesse sentido, destaca-se o corte de tipo epigênico (garganta de superimposição) do rio Paraopeba conhecido como "Fecho do Funil", entre os municípios de Brumadinho e Juatuba. O SGRV é uma sequência tipo greenstone belt, com predomínio de xistos e filitos que tendem a apresentar menor resistência relativa ao entalhe da drenagem (CHAVES, 2011; CARVALHO et al., 2019). Entre 710 a 820m de altitude, veios de quartzo e diques oferecem maior resistência aos processos erosivos, atuando como níveis de base locais que condicionam os processos hidrossedimentares (BARROS; MAGALHÃES JÚNIOR., 2018; CARVALHO; MAGALHÃES JÚNIOR., 2019a). No caso do GB, presente na bacia do médiobaixo Paraopeba, predominam calcários, ardósias e siltitos, e sua ocorrência condiciona a formação de vales abertos e relevo suavizado e deprimido em relação às áreas do EC e do SGRV (CPRM, 2003).

$\mathrm{Na}$ bacia, ocorrem níveis deposicionais escalonados e pareados em certos vales, como respostas à dinâmica conjunta entre os processos tectônicos de soerguimento regional e de blocos locais, com os ritmos climáticos quaternários (BARROS; MAGALHÃES JÚNIOR, 2018; 2020). Nas bacias do alto e médio curso, os vales tendem a ser mais encaixados e mais sujeitos à dinâmica dos processos de encostas, os quais podem remover rapidamente os registros deposicionais de níveis fluviais inativos. 
Além do escalonamento natural do perfil longitudinal do Paraopeba, os barramentos ao longo do vale (o da termelétrica de Igarapé, mais a montante, e os das usinas hidrelétricas de Salto do Paraopeba e de Retiro Baixo) também contribuem para a seleção do tipo de carga sedimentar transportada pelos fluxos. Portanto, a tendência geral é de retenção dos sedimentos mais grossos a montante dos barramentos e de transporte dos sedimentos mais finos em suspensão a distâncias maiores, vencendo os referidos níveis de base (BARROS; MAGALHÃES JÚNIOR, 2020; BRIERLEY; FRYIRS, 2005). Os cursos d'água da região apresentam regime fluvial fortemente sazonal, com elevação das vazões e ocorrência de inundações entre outubro e março, refletindo o padrão climático, no caso, tipicamente tropical, conforme a maioria dos rios brasileiros (BARTORELLI, 2012).

\section{TENDÊNCIAS DE ALTERAÇÕES GEOMORFOLÓGICAS}

As tendências de alterações geomorfológicas identificadas levaram à proposição de cinco trechos fluviais com características particulares. As figuras 2 e 3 ilustram a localização e os limites de referência dos trechos, enquanto a tabela 2 apresenta alguns dados morfométricos que os caracterizam. A descrição dos trechos, realizada a seguir, explicita a identidade de cada um em relação aos aspectos hidrogeomorfológicos. 


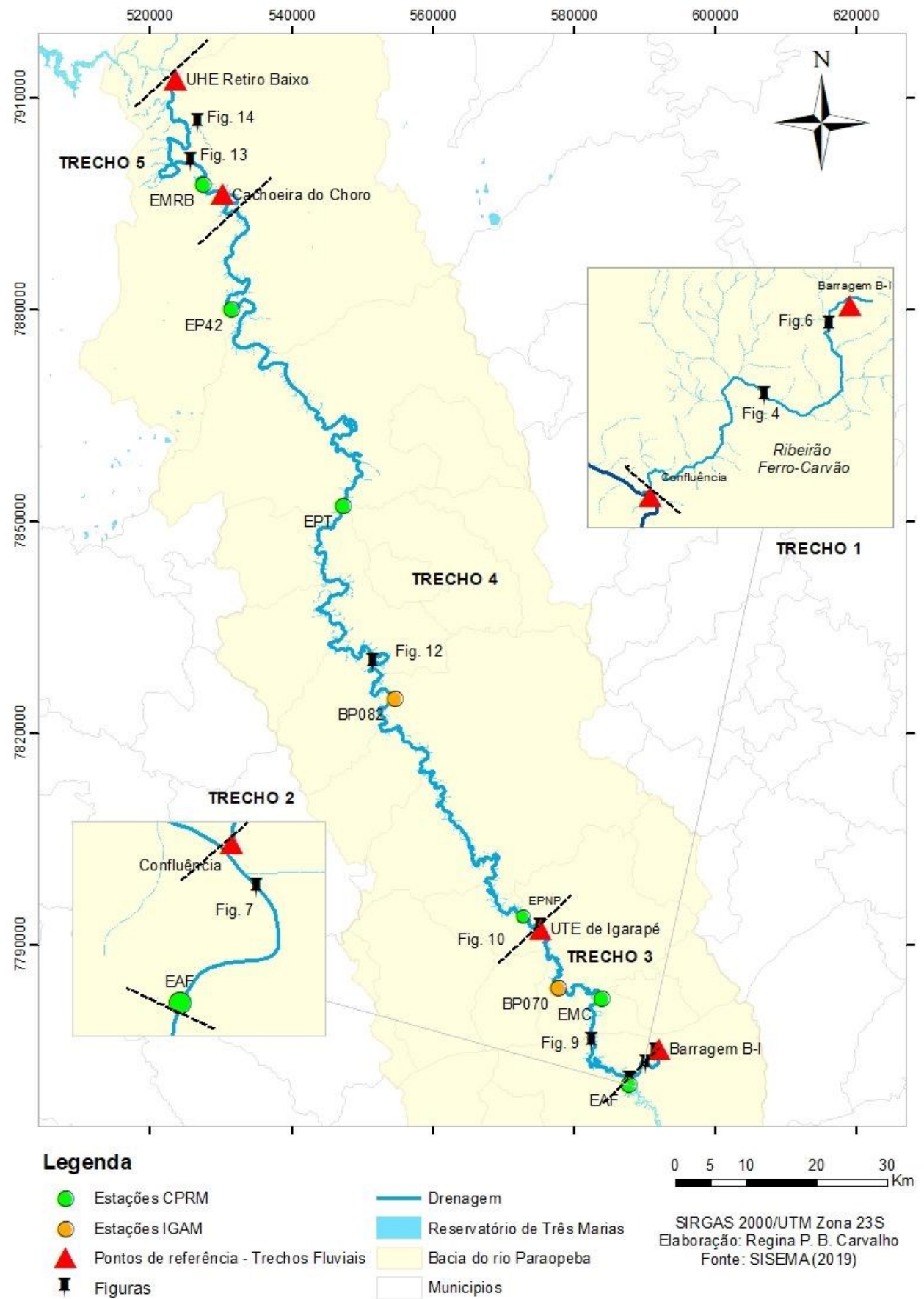

Figura 2 - Trechos fluviais, estações hidrossedimentológicas e locais das figuras ilustrativas de cada trecho.

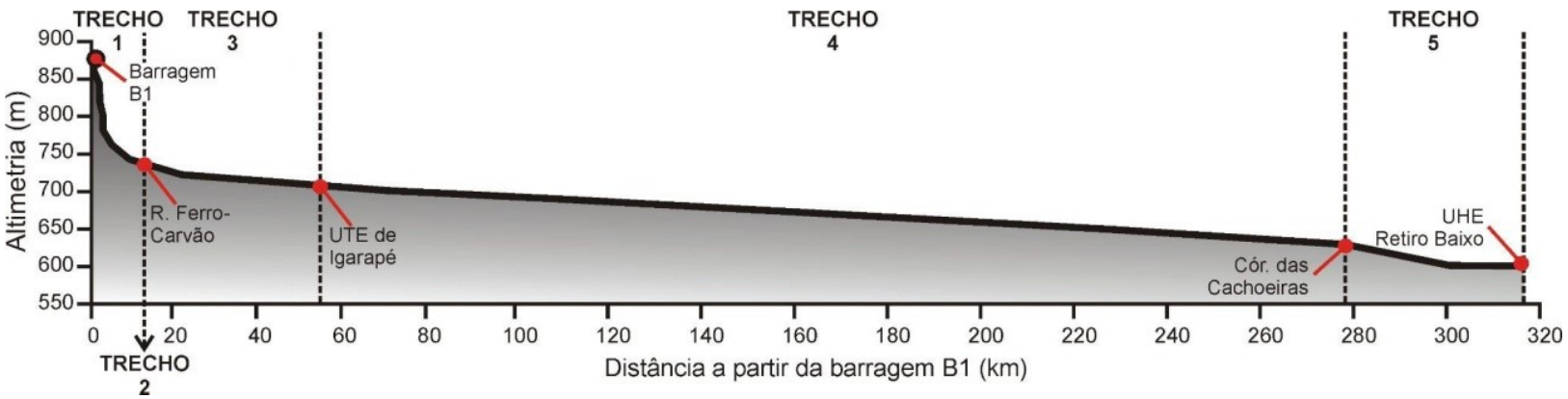

Figura 3 - Perfil longitudinal da rota do rejeito e trechos fluviais identificados. 
Tabela 2: Dados morfométricos dos trechos fluviais e dos cursos d'água.

\begin{tabular}{ccccc}
\hline Trecho* & Extensão (km) & $\begin{array}{c}\text { Amplitude } \\
\text { altimétrica (m) }\end{array}$ & $\begin{array}{c}\text { Índice de } \\
\text { Sinuosidade }\end{array}$ & $\begin{array}{c}\text { Gradiente do } \\
\text { Canal (\%) }\end{array}$ \\
\hline $\mathbf{1}$ & 9,95 & 145 & 1,14 & 14,57 \\
$\mathbf{3}$ & 45,13 & 29 & 1,11 & 0,64 \\
$\mathbf{4}$ & 223,72 & 72 & 1,25 & 0,32 \\
$\mathbf{5}$ & 38,48 & 34 & 1,10 & 0,88 \\
\hline
\end{tabular}

*Ribeirão Ferro-Carvão - Trecho 1; rio Paraopeba - Trechos 3 a 5. O Trecho 2 é muito curto para a obtenção dos dados na escala utilizada.

\subsection{Trecho 1}

O Trecho 1 se estende da barragem B1, na bacia do ribeirão Ferro-Carvão, até a confluência com o rio Paraopeba (Brumadinho), englobando a área diretamente impactada pelo rompimento, também denominada área de deposição de rejeito - ADR (COPPE, 2020). Os dados de sinuosidade (Tabela 2) mostram que, ainda que o Ferro-Carvão constitua o trecho mais a montante da área de estudo e marcado pelo maior gradiente do canal, ele apresenta o segundo maior Índice de sinuosidade $(1,14)$, o que tende a favorecer processos deposicionais e a retenção do rejeito.

Antes do rompimento, boa parte do fundo do vale era coberto por vegetação, inclusive a de aspecto paludial que caracteriza a presença de áreas úmidas dispersas na planície. Neste sentido, a vegetação encobria boa parte do espelho d'água, dificultando a observação do ribeirão nas imagens. Com o rompimento este trecho foi marcado pelo soterramento do fundo do vale, incluindo a planície fluvial e os baixos terraços do Ferro-Carvão (identificados em visitas antes do rompimento) - Figuras 4 e 5 . A grossa camada de rejeito, de até $20 \mathrm{~m}$ de espessura, atingiu cerca de $10 \mathrm{~km}$ de comprimento até a confluência, envolvendo um volume de cerca de 9,8 $\mathrm{Mm}^{3}$ (IGAM, 2020b). 

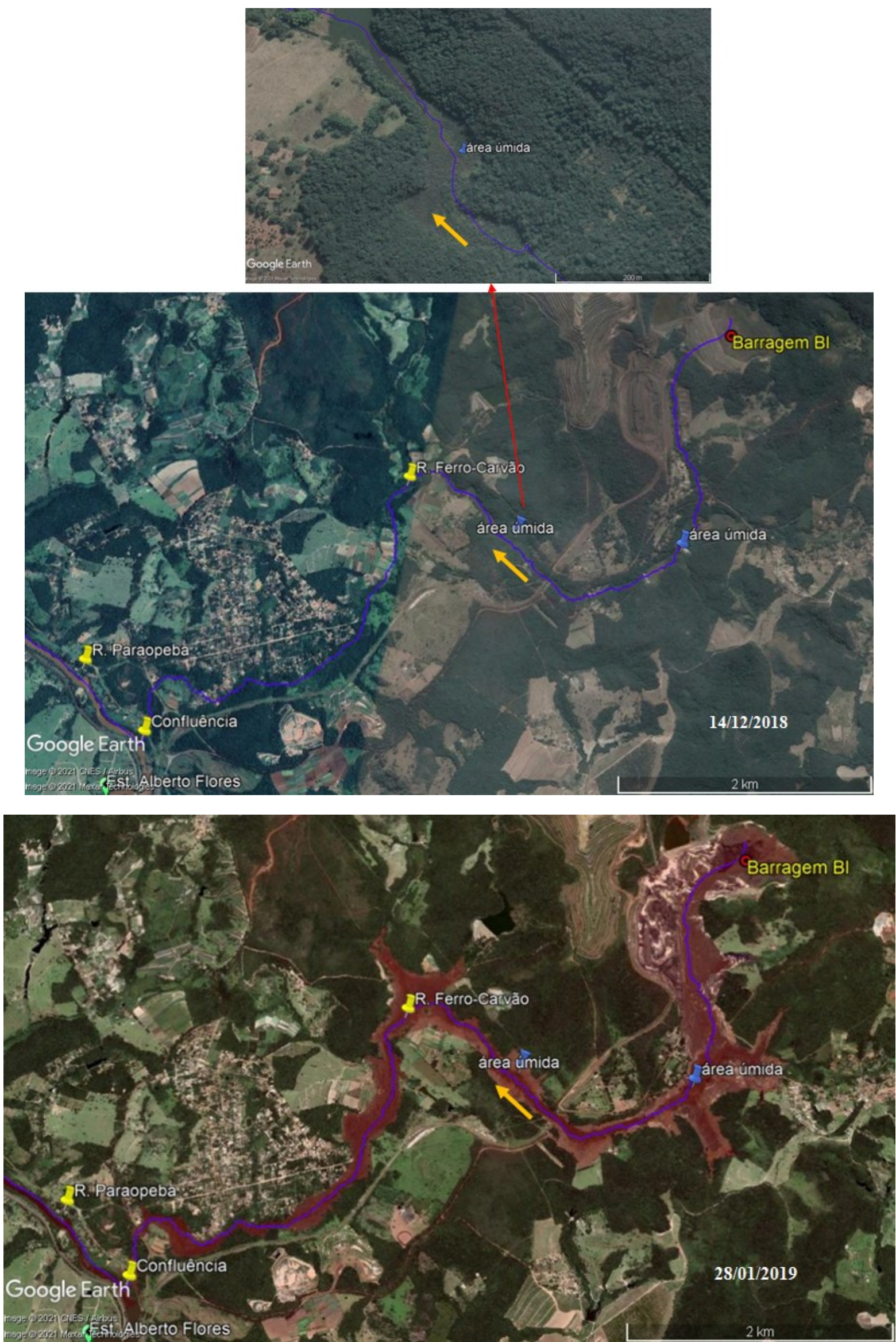

Figura 4 - Soterramento do fundo do vale do ribeirão Ferro-Carvão no Trecho 1 e encarte ilustrando sistema de áreas úmidas impactadas.

Fonte: imagem@2021 CNES/Airbus extraída do Google Earth®. 

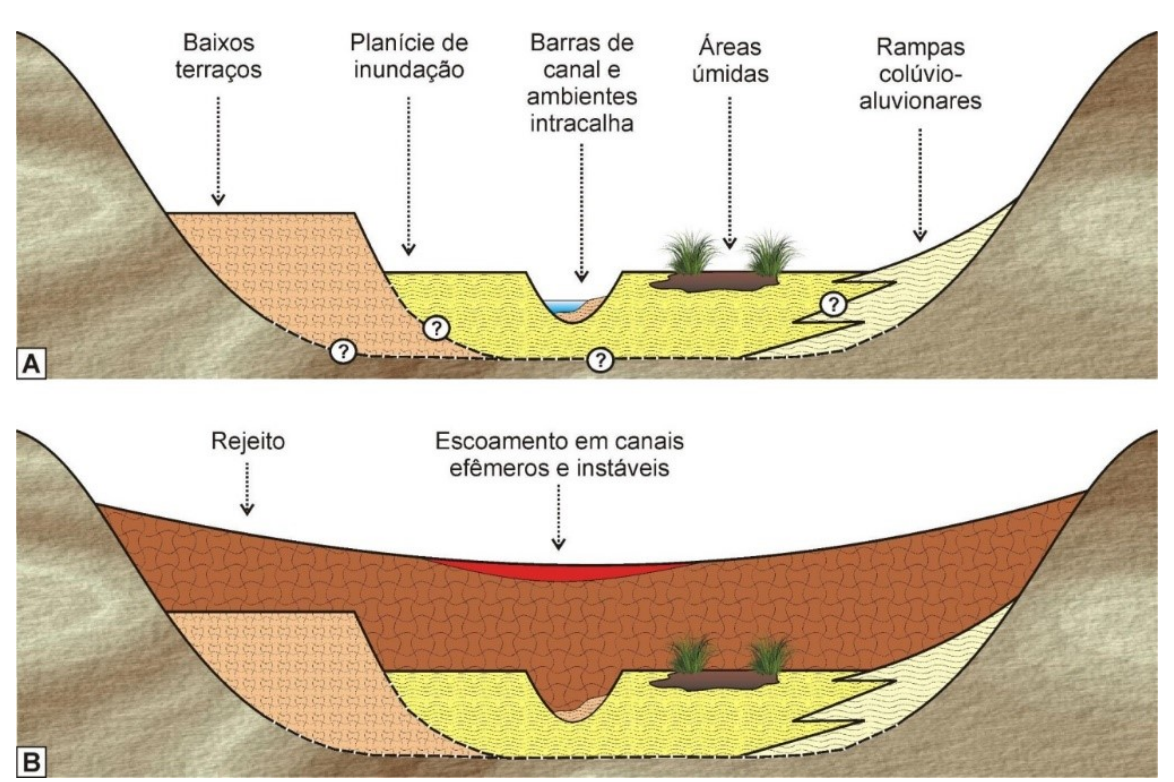

Figura 5 - Representação esquemática dos impactos do rompimento na configuração geomorfológica do fundo do vale do ribeirão Ferro-Carvão no Trecho 1. A) Quadro Pré-rompimento; B) Quadro pós-rompimento.

De acordo com o laudo da Perícia Criminal Federal, (MJSP, 2019, p. 124), o fluxo de rejeito apresentou comportamento semelhante ao de um fluido viscoso denso (MJSP, 2019). Amostras coletadas no rio Paraopeba mostraram que as partículas em suspensão se decantam em grande velocidade, indicando que o rejeito mobilizado é formado principalmente por partículas finas: 69,7\% de silte-argila e apenas 30,3\% de areia, com constituição química marcada por maiores concentrações de Ferro, Alumínio, Manganês e Titânio (VERGILIO et al., 2020). Porém, amostras coletadas em 31/01/2019 indicaram teores de Ferro, Bário, Cobre e Manganês acima da média dos solos da região, sendo que próximo à confluência as concentrações foram de 148.029, 153, 74 e $13.951 \mathrm{mg} / \mathrm{kg}$, respectivamente (MINISTÉRIO DA SAÚDE, 2020).

As imagens de março de 2019 mostram que, mesmo com o vale soterrado, o Ferro-Carvão vem entalhando o rejeito. Isto também ocorre por parte de fluxos pluviais que formam sulcos erosivos e vem reafeiçoando as cabeceiras (Fig. 6).

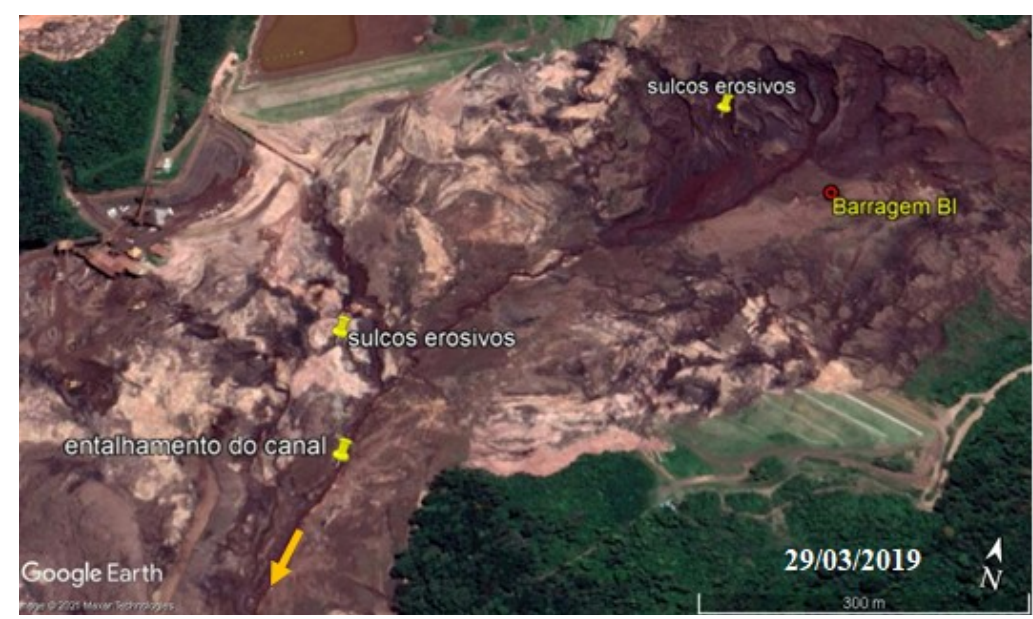

Figura 6 - Segmento superior do Trecho 1 soterrado e entalhado pelo ribeirão Ferro-Carvão e por fluxos pluviais.

Fonte: imagem@2021 CNES/Airbus extraída do Google Earth®. 
Com o desastre, o Ferro-Carvão perdeu a sua configuração original e os fluxos perderam a relativa estabilidade anterior, levando a novos traçados e novas conexões no fundo do vale. A massa de rejeito é densa e formada basicamente por materiais muito finos, particularmente silte-argila (VERGILIO et al., 2020), os quais são facilmente removidos em quadros de baixa agregação e resistência. Por isso, são comuns os sulcos erosivos na massa de rejeito ao longo da área afetada. Neste sentido, o rejeito acumulado passou a ser uma fonte contínua de sedimentos a partir da erosão por fluxos pluviais, nas áreas marginais, e fluviais, no leito e margens, comprometendo a estabilidade morfodinâmica dos cursos d'água.

Neste contexto, a rede de drenagem vem entalhando discretamente o rejeito e, ao mesmo tempo, adquirindo uma configuração mais sinuosa que foi perdida quando do rompimento. Os processos de encaixamento são, por outro lado, freados pelos reflexos do rompimento a jusante, dado que o entulhamento na confluência elevou, de modo relativo, o nível de base (rio Paraopeba). A relação entre a capacidade de encaixamento do Ferro-Carvão no substrato e a sua migração lateral é decisiva para a reconfiguração das áreas marginais, incluindo os sistemas de áreas úmidas (wetlands) na planície. O Trecho 1 também suscita outras questões relativas aos riscos de remoção e transporte de sedimentos finos e elementos químicos (metais ou não) para jusante, a longo prazo, colocando em risco permanente a qualidade ambiental e a segurança hídrica na bacia.

\subsection{Trecho 2}

Este trecho inicia-se a partir da estação fluviométrica EAF, localizada um quilômetro a montante da confluência do Paraopeba com o ribeirão Ferro-Carvão (CPRM, 2019). O fundo do vale é aberto e com planície que foi recoberta pelo rejeito. Portanto, a identidade do Trecho 2 decorre da expressiva deposição de rejeito na confluência, principalmente na margem esquerda (Fig. 7). Entre os dias 26/01 e 30/04/2019, a referida estação registrou uma descarga sólida suspensa na média de $66 \mathrm{mg} / \mathrm{L}$ de sedimentos e máximas de $135 \mathrm{mg} / \mathrm{L}$, tendo a carga de fundo a textura predominante de areia fina (CPRM, 2019a).

Os fluxos fluviais ocuparam parte das margens como reflexo inicial da onda de rejeito, retornando posteriormente ao leito menor. A partir de então, a dinâmica hidrossedimentar contribuiu para o desenvolvimento da margem convexa do meandro no Trecho (barra de pontal).

A redução da granulometria dos sedimentos de fundo e a baixa vazão média registrada no primeiro trimestre após o rompimento, a montante da confluência, indicam que houve o remanso do fluxo do Paraopeba nos primeiros dias após o desastre, fazendo com que o rejeito fosse mobilizado e depositado a montante, na altura da estação EAF (Fig. 8). Efetivamente, a lama acumulada provocou, na tarde de 25 de janeiro de 2019, um remanso a montante da confluência que levou a uma elevação 
do nível de água que atingiu $5 \mathrm{~m}$ acima do normal na referida estação (CPRM, 2019a). Como resultado, formou-se um grande depósito de rejeito na margem esquerda do Paraopeba na confluência (oposta ao Ferro-Carvão), bloqueando os fluxos e levando à redução e a um certo "confinamento" do leito rumo à margem direita, além da abertura de uma ramificação no canal principal (Fig. 7 e 8). Esse confinamento provocou a reconfiguração das margens na área de confluência do Paraopeba com o rio Casa Branca, a montante da confluência com o Ferro-Carvão.
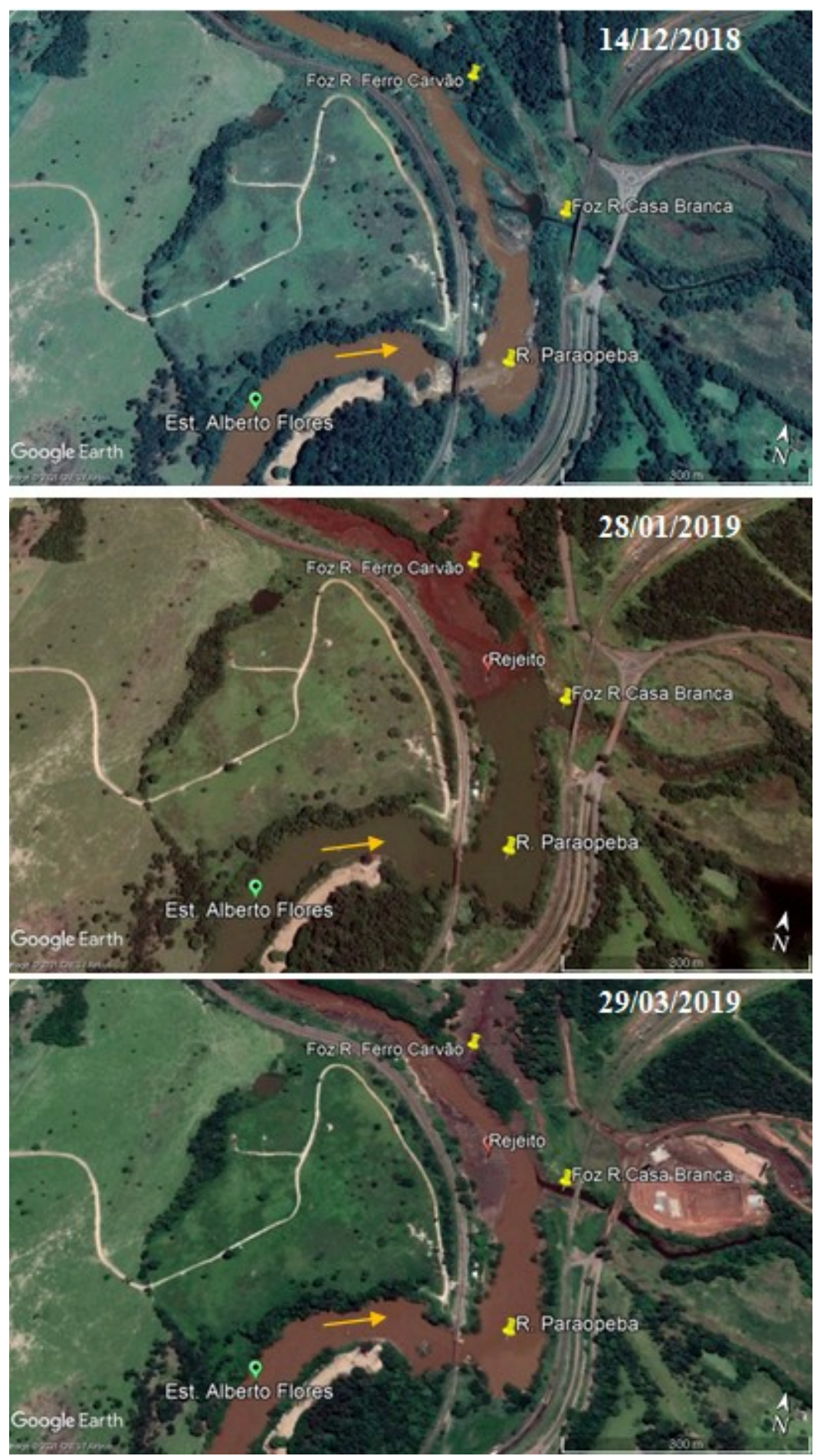

Figura 7 - Deposição de rejeito e deslocamento da calha do rio Paraopeba para a margem direita no Trecho 2. Fonte: imagem@2021 CNES/Airbus extraída do Google Earth®. 

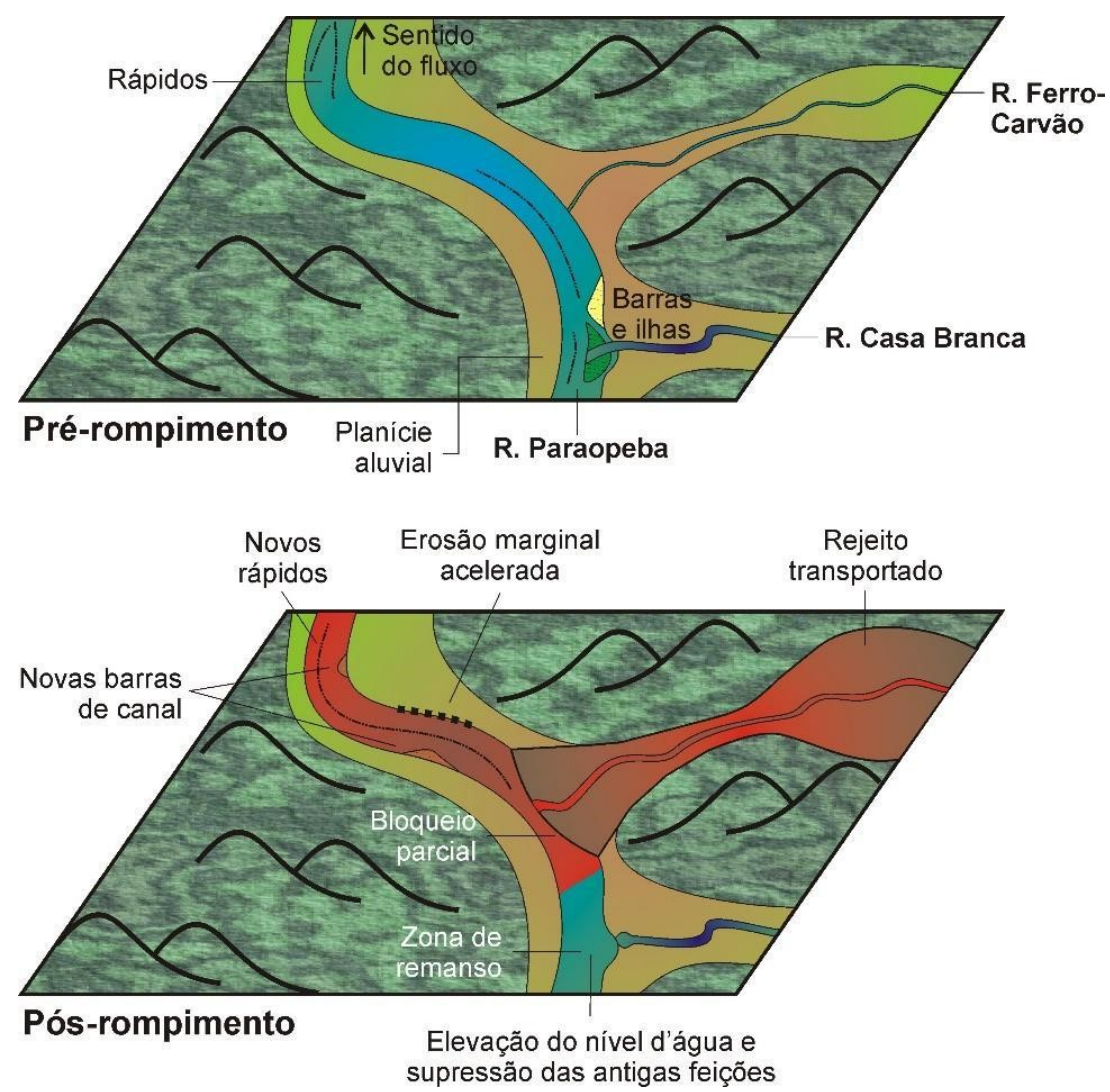

Figura 8 - Representação esquemática dos impactos do rompimento na configuração geomorfológica de fundos de vales no Trecho 2 e início do Trecho 3.

Apesar das imagens de satélite registrarem tais alterações morfológicas, a estação EAF não identificou mudanças no perfil transversal do Paraopeba em função da deposição de rejeitos a jusante (CPRM, 2019a). Esta estação possui dados históricos do comportamento fluvial do Paraopeba e, segundo as medições, entre 2002 a 2018, nos meses de janeiro, fevereiro, março e abril, a vazão média no local foi de $122,2 \mathrm{~m}^{3} / \mathrm{s}, 97,9 \mathrm{~m}^{3} / \mathrm{s}, 81,7 \mathrm{~m}^{3} / \mathrm{s}$ e $56,3 \mathrm{~m}^{3} / \mathrm{s}$ respectivamente. Contudo, após o rompimento, a coleta de dados vazão ficou comprometida, inviabilizando alguns levantamentos até meados de fevereiro. Após esse período, o funcionamento da estação foi normalizado, registrando vazão média de 59,9 m³/s entre 14/02/2019 e 24/04/2019 (CPRM, 2019a), valor relativamente baixo quando comparado à média mensal histórica e considerando que as chuvas de 2019 se concentraram entre fevereiro e março.

\subsection{Trecho 3}

Este Trecho se estende da confluência do Paraopeba com o Ferro-Carvão, até pouco a montante do barramento da UTE de Igarapé, em Juatuba. As alterações ocorreram principalmente pela formação de barras de canal longitudinais no leito do Paraopeba, a jusante da confluência (Fig. 9). O surgimento expressivo destas feições entre o final de janeiro e março de 2019 reflete a configuração mais confinada do vale, com menos ambientes marginais passíveis de inundação. Desse 
modo, a quantidade de barras de canal no Trecho 3 são indícios do volume de rejeito ejetado no Paraopeba. Por outro lado, a dinâmica das vazões influencia a exposição e, consequentemente, a visualização das barras de canal por meio das imagens (Fig. 9). Devido à forte dinâmica das vazões ocasionada pelo volume de rejeitos e pelo regime fortemente sazonal, os depósitos são dinâmicos e instáveis, com o rejeito sendo ora depositado, ora removido, ficando ora emerso e ora submerso pelos fluxos.
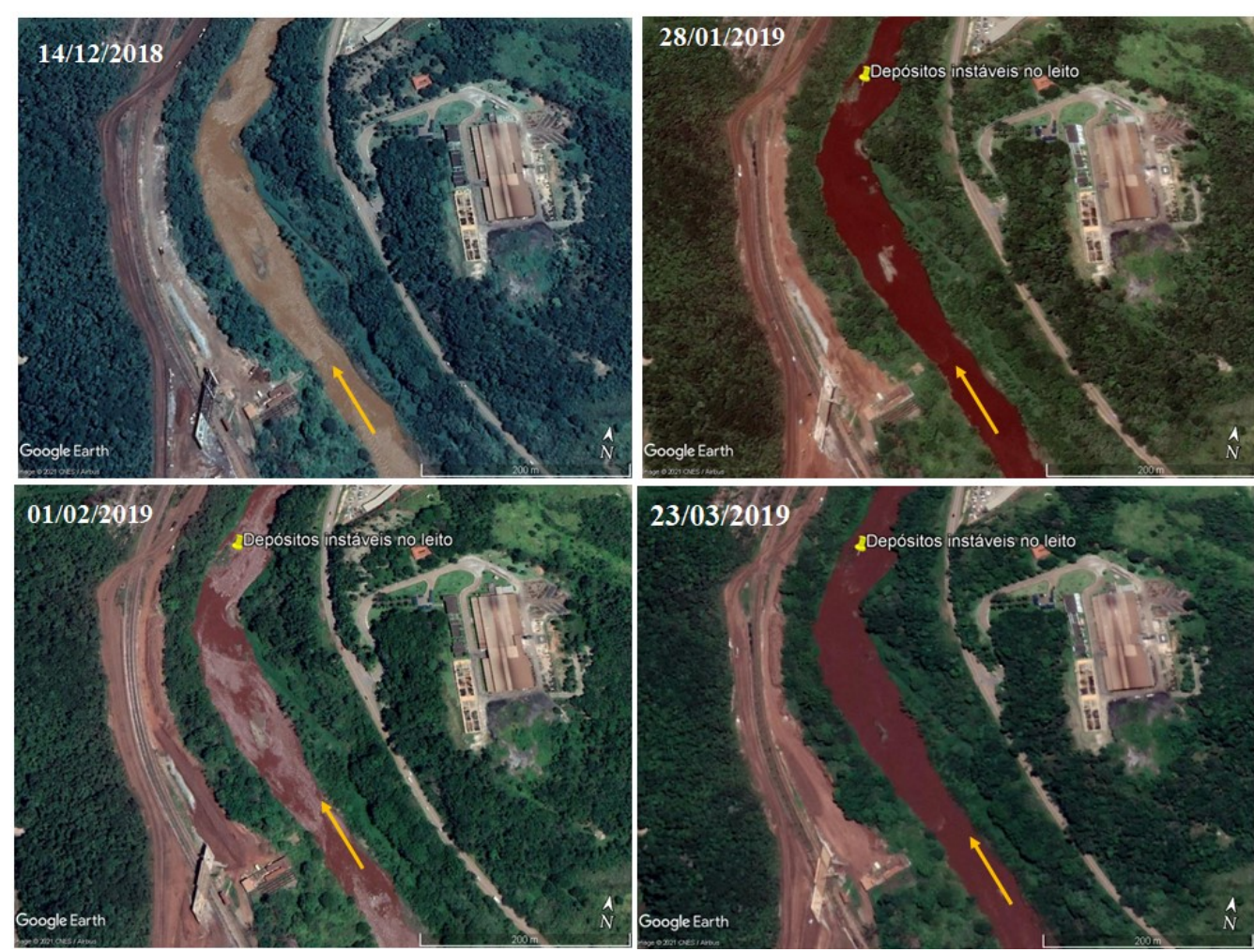

Figura 9 - Reconfiguração e surgimento de barras de canal no rio Paraopeba (Trecho 3).

Fonte: imagem@2021 CNES/Airbus extraída do Google Earth®.

A jusante do local mostrado na Figura 9, na estação EMC, a jusante do Fecho do Funil, a vazão foi de 25,9 m³/s em 30/01/2019 e 85,3 m³/s em 13/03/2019, indicando que a elevação do nível d'água provavelmente provocou o recobrimento de diversas barras de canal neste trecho (CPRM, 2019). As barras estão mais concentradas até a altura da garganta epigênica do Fecho do Funil, onde o rio Paraopeba corta a Serra de Igarapé. Esta feição é um nível de base regional que atuou como uma barreira geomorfológica ao escoamento dos sedimentos ao longo do Quaternário Tardio (BARROS; MAGALHÃES JÚNIOR, 2018).

Ainda na estação EMC, a série histórica do CPRM de 2002 a 2018 registrou concentrações máximas de $5.000 \mathrm{mg} / \mathrm{L}$ para sedimentos suspensos. Entre 26/01 a 30/04/2019, as concentrações máximas dobraram, chegando a $10.000 \mathrm{mg} / \mathrm{L}$ em menos de 4 meses. No mesmo período pósrompimento, registrou-se a mobilização de cerca de 512 a 534 mil toneladas de sedimentos totais (CPRM, 2019a). Considerando a densidade do minério deslocado $\left(2 \mathrm{t} / \mathrm{m}^{3}\right)$, o volume de sedimentos 
em suspensão até a referida estação foi de cerca de $235.000 \mathrm{~m}^{3}$ no mesmo período (CPRM, 2019a). Esse valor é bastante inferior ao volume de rejeito da barragem $\left(11,7 \mathrm{M} \mathrm{m}^{3}\right)$ e mostra que, até o final do período chuvoso de 2019, boa parte do rejeito ainda não tinha chegado até a Estação, indicando que esse material ainda poderia ser mobilizado pelo rio Paraopeba.

Dados complementares de sólidos totais registrados pelo IGAM entre 1997 e 2018 mostram que, na estação São Joaquim de Bicas, os valores médios foram de 160,4 mg/L, com máximas de 861 $\mathrm{mg} / \mathrm{L}$. No entanto, após o rompimento, em um curto período de três meses (25/01 até final de abril de 2019), a média foi de 713,02 mg/L - quatro vezes maior do que a média histórica - e a máxima de $5.082 \mathrm{mg} / \mathrm{L}$, valor quase seis vezes maior do que as máximas registradas no citado período de 21 anos.

As imagens mostram que logo após o rompimento a cor da água apresentou um forte tom vermelho como reflexo da brusca elevação da turbidez. Historicamente, a cor verdadeira do rio Paraopeba registrou médias de 69Upt na estação São Joaquim de Bicas (IGAM); a média dos noventa primeiros dias após o rompimento foi de 65,59 Upt. Portanto, não foram observadas variações bruscas na cor verdadeira no trimestre posterior ao desastre em relação à média histórica, indicando que a maior parte dos sedimentos em suspensão derivados do rompimento foi retida a montante da estação.

No dia 26 de janeiro, novamente na estação de EMC, foi registrado um aumento de até 2 mil NTU de turbidez, e de 10 mil NTU em 31 de janeiro. A partir de 01 de fevereiro até meados de abril, a turbidez variou entre 3 e 10 mil NTU, com picos de elevação nos eventos chuvosos, em especial entre os dias 4 a 8 e 13 a 22 de fevereiro, quando atingiu valores acima de 20 mil NTU (CPRM, 2019a).

Em relação à granulometria de fundo, antes do rompimento, estudos mostram a predominância de areia fina a muito grossa em São Joaquim de Bicas (1982 a 1994) e, após o rompimento, de areia média em EMC, indicando que antes a fração dos sedimentos de fundo era maior do que após o desastre (CPRM, 2019a). Já em relação ao diâmetro dos sedimentos suspensos, houve maior variação ao longo do tempo, o que pode ser reflexo das variações da vazão e, portanto, da dinâmica de transporte fluvial após as chuvas de fevereiro e março. Entre 25/01/2019 a 24/04/2019, a vazão média registrada foi de $25,8 \mathrm{~m}^{3} / \mathrm{s}$ e a máxima de $135,5 \mathrm{~m}^{3} / \mathrm{s}$ (CPRM, 2019a).

\subsection{Trecho 4}

O Trecho 4, a jusante do barramento da UTE de Igarapé (Juatuba), estende-se até a confluência do Paraopeba com o córrego das Cachoeiras, próximo à comunidade de Cachoeira do Choro (município de Curvelo). Neste trecho, o rio Paraopeba apresenta o mais baixo gradiente $(0,32 \%)$ e o maior Índice de sinuosidade $(1,25)$ da área, características menos favoráveis ao transporte 
de sedimentos grossos e mais propensas à formação de ambientes deposicionais de baixa energia e, consequentemente, à retenção do rejeito.

Este é o trecho de maior extensão, sendo marcado pelo recobrimento de feições fluviais de leito (ilhas e barras de canal) e ambientes marginais pelos fluxos carregados de rejeito (CPRM; IGAM, 2019) - Fig. 10 e 11.

Após o rompimento, ocorreu importante elevação da turbidez da água devido não só à pluma de rejeito, mas também ao aumento da vazão com a chegada das chuvas. A alteração da cor está diretamente associada à elevação da carga de sólidos totais após o rompimento e indica, portanto, que o rejeito já tinha chegado ao Trecho 4 no início de fevereiro. Como mostra a Figura 10, a água do Paraopeba tinha um tom aparente marrom claro, passando a apresentar, a partir do desastre e da chegada das chuvas (IGAM, 2020a), tonalidade marrom escura e avermelhada. Dados da estação BP082 (IGAM) - no rio Paraopeba em Esmeraldas - indicam que a média histórica da cor verdadeira neste trecho é de $76 \mathrm{Upt}$, acima, portanto, do limite previsto para rios Classe 2 (COPAM N01/2008). Entre o rompimento e o final de abril de 2019, a média girou em torno de 97,54 Upt, revelando um aumento de 1,3 vezes acima do máximo permitido na legislação. A mesma estação registrou uma média de 265,18 mg/L e máxima de $1.890,0 \mathrm{mg} / \mathrm{L}$ de sólidos totais, sendo a média e a máxima histórica neste ponto de $167,5 \mathrm{mg} / \mathrm{L}$ e $810 \mathrm{mg} / \mathrm{L}$, respectivamente (IGAM, 2019).
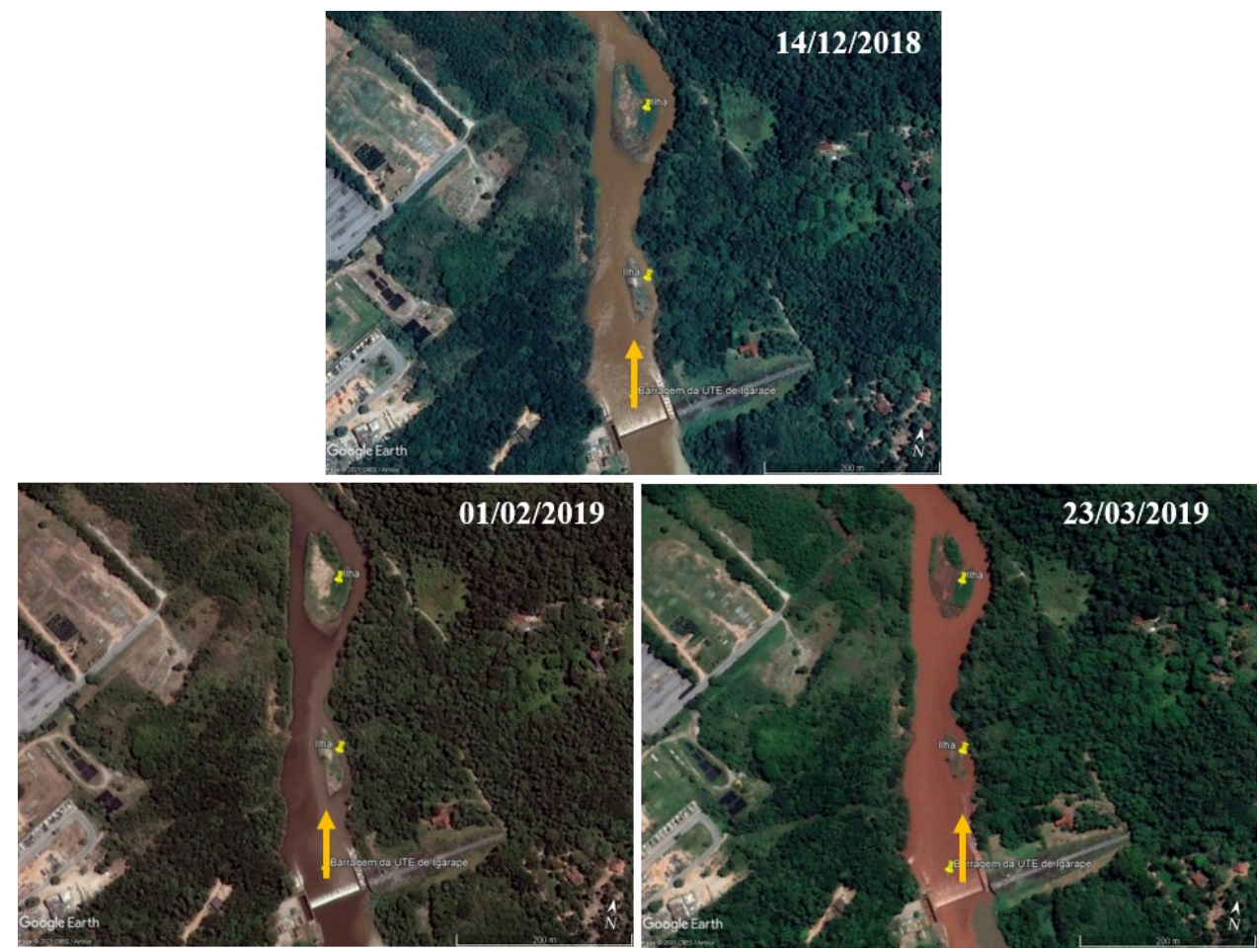

Figura 10 - Imagens ilustrando o recobrimento de feições de leito pela elevação do nível d'água e o aumento da turbidez no Trecho 4.

Fonte: imagem@2021 CNES/Airbus extraída do Google Earth®. 

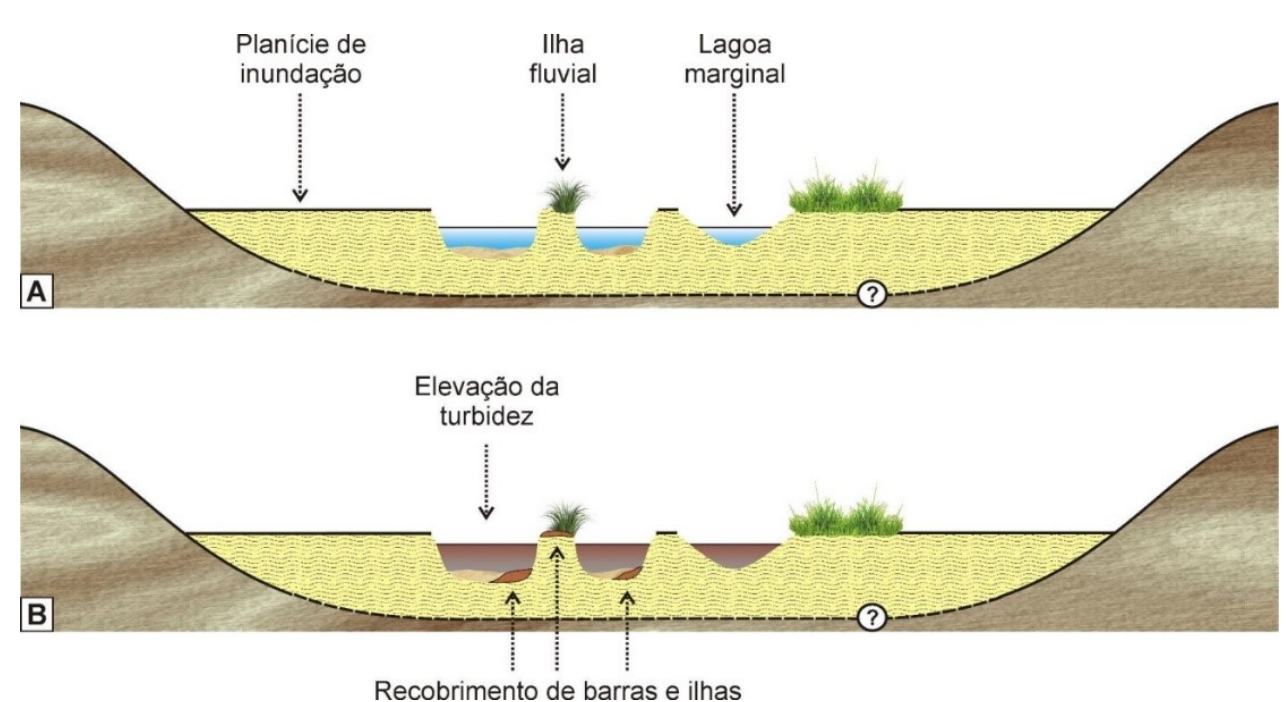

Figura 11 - Representação esquemática dos impactos do rompimento na configuração geomorfológica do fundo do vale do rio Paraopeba nos trechos 4 e 5. A) Quadro Pré-rompimento; B) Quadro pós-rompimento.

O recobrimento ou a exposição de feições deposicionais na área deve considerar, também, a dinâmica temporal das vazões, dado que a elevação do nível d'água na estação chuvosa pode encobrir ilhas e barras de canal, independentemente do evento do rompimento. Na estação EPNP, pouco a jusante do local mostrado na Figura 9, o histórico das vazões médias mensais em janeiro, fevereiro, março e abril mostra, respectivamente, valores de 172, 143, 128 e $85 \mathrm{~m}^{3} / \mathrm{s}$. No dia do rompimento, a vazão registrada nessa estação foi de $35 \mathrm{~m}^{3} / \mathrm{s}$, e a média mensal das vazões de fevereiro, março e abril de 2019 foi de 65, 66 e $48 \mathrm{~m}^{3} / \mathrm{s}$, ou seja, muito abaixo da média histórica. Dados da mesma estação mostram que no dia 01/02/2019 a vazão foi de 27,4 m³/s, com o nível do rio chegando a $105 \mathrm{~cm}$.; e no dia 20/03/2019, a vazão atingiu 70,7 m³/s com o nível alcançando $153 \mathrm{~cm}$. Isto mostra que, a partir do rompimento, houve, no início de fevereiro, uma redução do fluxo d'água, seguida de elevação no mês posterior, aumentando a capacidade de transferência de sedimentos (rejeito). Já na estação EPT, as vazões registradas após a ruptura da barragem estiveram de acordo com as medições realizadas em 2018 (vazão média de $78 \mathrm{~m}^{3} / \mathrm{s}$ ) e, portanto, não apresentaram alterações possivelmente relacionadas ao rompimento (CPRM, 2019a). Imagens também mostram que ao longo da estação chuvosa houve o recobrimento de barras de canal pelos fluxos do Paraopeba (Fig. 12). A remobilização contínua dos rejeitos a montante forneceu elevada carga sedimentar para o recobrimento das barras.
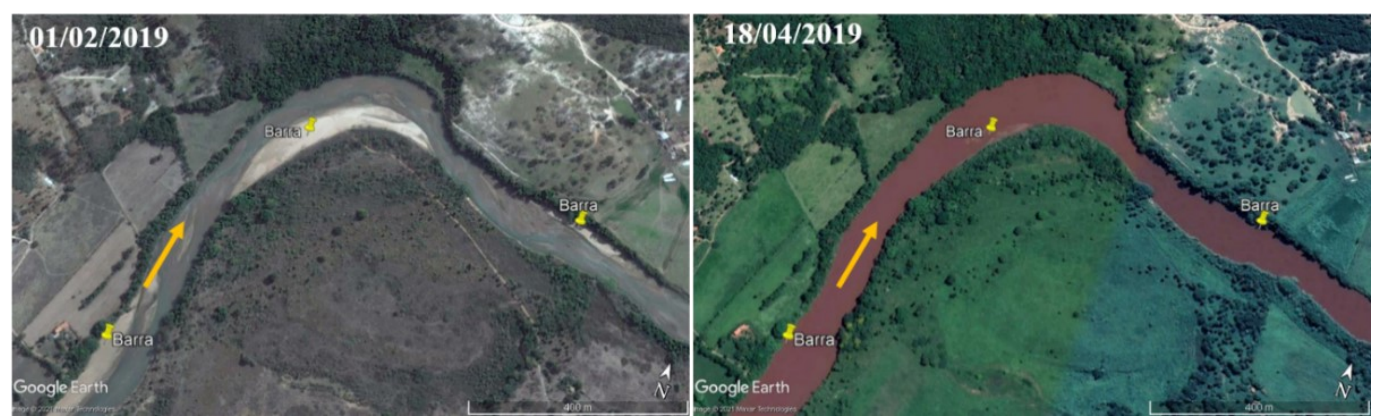

Figura 12 - Submersão de barras de canal no Trecho 4 após elevação do nível do rio Paraopeba.

Fonte: imagem@2021 CNES/Airbus extraída do Google Earth®. 
Esse panorama pode ser complementado com os dados de turbidez. Os maiores valores foram registrados entre 18 e 24 de fevereiro de 2019: 3 a 10 mil NTU na estação EPNP e 1,5 mil NTU na EPT(CPRM,2019; 2019a). Os valores máximos de sedimentos em suspensão da série histórica (1975 a 2018) atingiram $2.651 \mathrm{mg} / \mathrm{L}$ na EPNP, mas, após o rompimento, as concentrações medidas até 30 de abril de 2019 foram quase o dobro, chegando a $4.112 \mathrm{mg} / \mathrm{L}$. Nessa mesma estação, o diâmetro médio dos sedimentos foi de $9 \mu \mathrm{m}$. Já na estação EPT ocorreu o inverso: as maiores concentrações de sedimentos suspensos foram da média histórica (1972 a 1978) em relação à média após o rompimento, indicando importante retenção de sedimentos finos a montante. Nessa estação, o diâmetro médio dos sedimentos em suspensão foi de $11 \mu \mathrm{m}$. Em relação aos sedimentos de fundo, as análises mostraram que, nas duas estações predominava areia muito fina a grossa, passando a areia média após o rompimento (CPRM, 2019a). Entre 26/01 e 30/04/2019 foram mobilizadas de 279 a 283 mil toneladas de sedimentos totais na EPNP e entre 323 e 364 mil toneladas na EPT (CPRM, 2019a).

Ainda no Trecho 4 (montante de Cachoeira do Choro), na estação EP420, registrou-se uma elevação abrupta da turbidez de 900 NTU durante todo o dia 25/02/2019, valor nove vezes acima dos limites legais (COPAM/CERH, 2008). Nesta data, o boletim informativo do IGAM mencionou que, nas imediações do município de Paraopeba, a pluma de rejeito poderia ser identificada visualmente, dirigindo-se a jusante, a partir da uma mancha de coloração mais intensa (IGAM, 2019a).

\subsection{Trecho 5}

O Trecho 5 compreende o segmento do Paraopeba a partir do córrego das Cachoeiras, em Cachoeira do Choro, e se estende até o barramento do reservatório da Usina de Retiro Baixo, entre os municípios de Curvelo e Pompéu. A identidade deste trecho deriva do papel do reservatório como nível de base regional indutor de processos de inundação de fundos de vale e ocorrência de fluxos de retorno (remanso), potencializando a deposição de rejeito. O segmento mais a montante do Trecho possui corredeiras no leito do Paraopeba, as quais vão desaparecendo gradualmente para jusante à medida que a calha se alarga e o fluxo perde turbulência. Próximo à zona de remanso do barramento, o Paraopeba apresenta águas mais calmas que potencializam as tendências de deposição no sistema fluviolacustre.

Pôde-se constatar a mudança de tonalidade da cor da água devido à elevação da concentração de sólidos suspensos e dissolvidos e, consequentemente da turbidez, entre janeiro e março de 2019. A alteração foi expressiva em fevereiro devido ao aumento das chuvas, levando à inundação das margens e ao recobrimento de áreas úmidas como lagoas marginais (Fig. 13). 


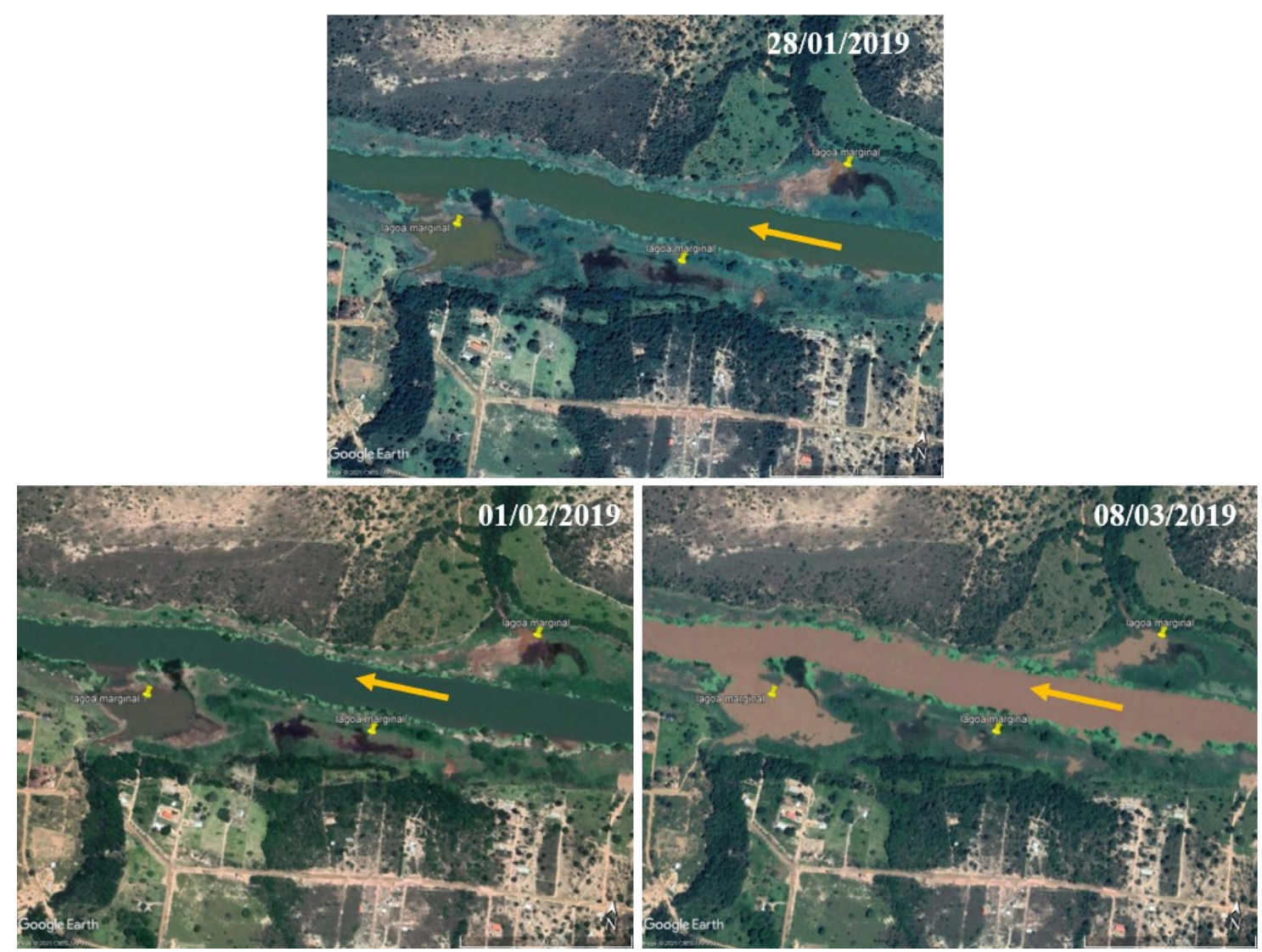

Figura 13 - Recobrimento de lagoas marginais no Trecho 5 a partir da elevação do nível do rio Paraopeba e aumento da turbidez da água (alterações de tonalidade).

Fonte: imagem@2021 CNES/Airbus extraída do Google Earth®.

Nesse trecho o registro sequencial das imagens do final de janeiro, fevereiro e março de 2019 reforçam as análises do IGAM (2019a; 2019b) que afirmam que a pluma de rejeito atingiu a barragem de Retiro Baixo entre fevereiro e março. Com o aumento das chuvas, que em 2019 foi bem expressivo no mês de fevereiro (IGAM, 2020a), houve o aumento das inundações e o avanço da pluma que cobriu o fundo do vale. Pode-se observar pela Figura 14 que ao longo do trimestre houve mudança na cor (aparente) da água, que passa gradualmente a apresentar tonalidade marrom clara no início de março. O avanço da pluma é observado na imagem por uma mancha de coloração mais intensa se estendendo para jusante e indicando elevação da carga de sedimentos em suspensão (IGAM, 2019a; 2019b). Efetivamente, durante todo o dia 25/02/2019 foi registrada, nos trechos 4 e 5, elevação abrupta da turbidez (acima de 900 NTU), nove vezes acima do limite estabelecido pelo COPAM/CERH (2008), no ponto EMRB, entre Curvelo e Pompéu (CPRM, 2019; 2019a). Essa elevação também contribui para explicar o aspecto turvo e a tonalidade marrom da água no mês de março. 


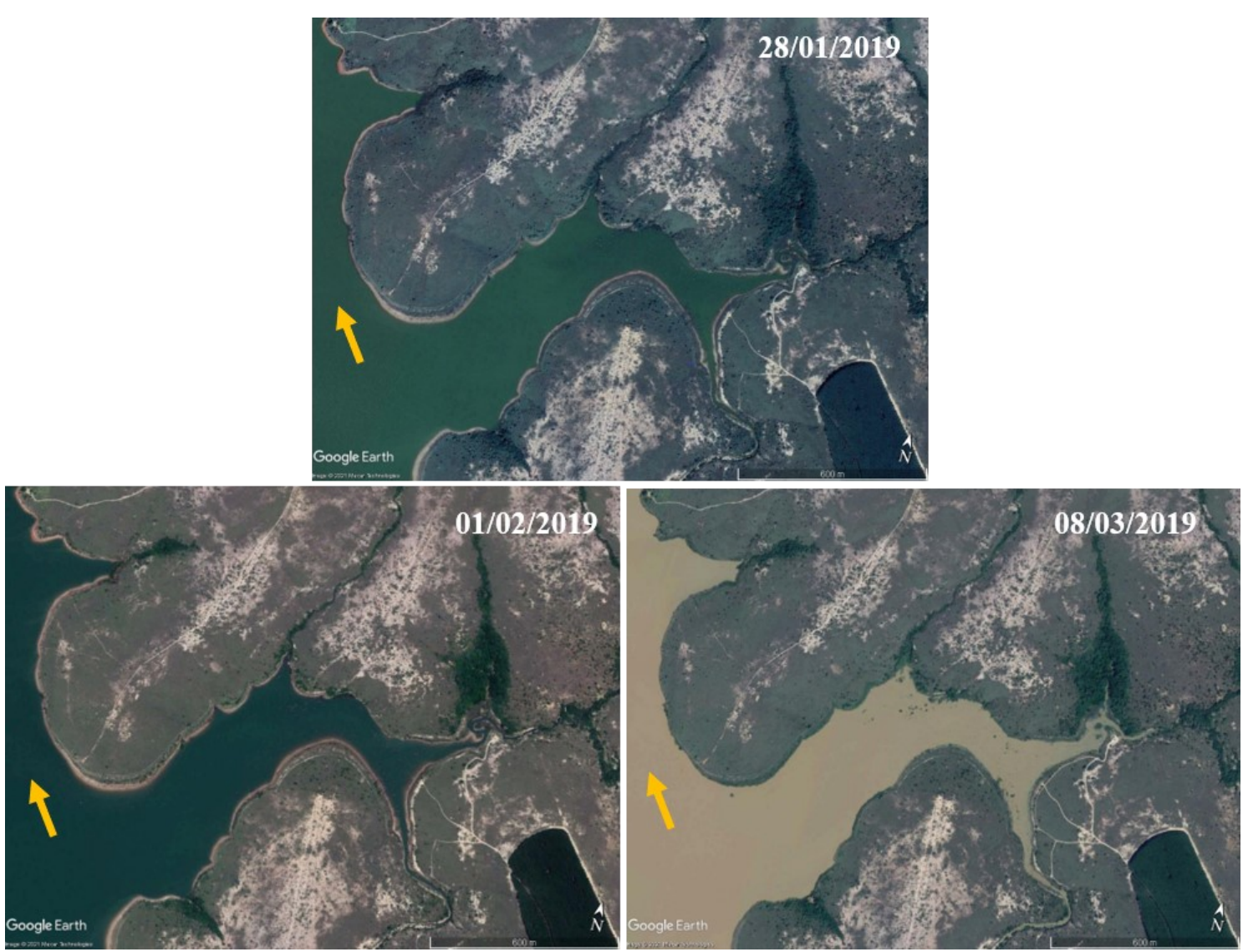

Figura 14 - Recorte do Trecho 5 ilustrando os processos de elevação do nível do reservatório de Retiro Baixo e o aumento da turbidez da água por meio da alteração de tonalidade.

Fonte: imagem@2021 CNES/Airbus extraída do Google Earth®.

\section{CONSIDERAÇÕES FINAIS}

A análise dos impactos do rompimento da barragem B-1 nos sistemas hidrogeomorfológicos de fundos de vales viabilizou a pesquisa em diferentes resoluções espaciais, abarcando séries históricas que permitem contemplar a dinâmica dos sistemas fluviais e a sua capacidade de adaptação às novas condições. No entanto, há a limitação da frequência do levantamento das imagens Google Earth, fazendo com que não haja dados históricos com as mesmas datas para a área de estudo como um todo. Outro ponto observado é a restrição de disponibilidade de imagens atuais, o que pode estar relacionado à gratuidade do software, o qual oferece acesso apenas a dados que não comprometem o mercado de imagens de alta resolução. Ressalta-se que, embora em alguns trechos não tenham sido observados claro impactos geomorfológicos na escala visual adotada, as alterações geomorfológicas ocorridas em grande escala (morfologia de fundo), potencialmente desencadeadas pelo fluxo de rejeito, também podem se desdobrar em diversos impactos para os ecossistemas e para a sociedade, e podem implicar, por exemplo, em danos a atividades de pesca e irrigação.

Sobre os dados hidrossedimentológicos da bacia do rio Paraopeba, a pesquisa utilizou, principalmente, as bases de dados oficiais do CPRM e IGAM. Esses dados contribuíram para caracterizar o comportamento e qualidade da água e dos sedimentos dos trechos identificados. 
Contudo, a ausência de uma padronização dos locais de amostragem e a frequência da análise dos parâmetros limitam as correlações espaciais para compreensão da geomorfodinâmica da área. Nesse sentido, o Trecho 1 não possui série de dados hidrossedimentológicos do CPRM e do IGAM, os trechos 2 a 5 apresentam dados somente do CPRM, e apenas os trechos 3 e 4 possuem dados do IGAM comparáveis, dentro do período de análise.

Apesar destas lacunas, foi possível identificar importantes alterações geomorfológicas pósdesastre. No Trecho 1, a proximidade com a barragem o transformou no principal segmento fluvial retentor de rejeito e também o mais impactado em termos geomorfológicos, com o soterramento do fundo do vale. Nos demais trechos, a formação de depósitos expressivos nas margens, o surgimento de barras de canal na calha do Paraopeba e o entulhamento de áreas de confluência e fundos de vale até o reservatório de Retiro Baixo são indicativos de consequências importantes do desastre que precisam continuar sendo avaliadas ao longo do tempo.

Os resultados mostram que os eventos de rompimento de barragens de rejeito tendem a desencadear efeitos na configuração geomorfológica dos fundos de vales, além dos conhecidos impactos socioambientais. O dimensionamento e a duração destes impactos são ainda desconhecidos em sua totalidade, exigindo a continuidade dos esforços de pesquisa no âmbito geomorfológico.

\section{AGRADECIMENTOS}

Ao CNPq pela bolsa de pesquisa e ao Grupo RIVUS - Geomorfologia e Recursos Hídricos.

\section{REFERÊNCIAS}

BARTORELLI, A. Contexto geológico e evolução da rede hidrográfica do Brasil. In: HASUI, Y.; CARNEIRO, C.D.R.; ALMEIDA, F.F.M.; BARTORELLI, A. (Eds.). Geologia do Brasil. São Paulo: Ed. Beca, 2012. p. 574-610.

BARROS, L. F. P.; MAGALHÃES JÚNIOR, A. P. Reconstituição de eventos geomorfológicos no Quadrilátero Ferrífero/MG a partir de registros deposicionais fluviais: a bacia do rio Paraopeba. Quaternary and Environmental Geosciences, v. 9, p. 36-48, 2018.

BARROS, L. F. P.; MAGALHÃES JR., A. P. Late quaternary landscape evolution in the Atlantic Plateau (Brazilian highlands): Tectonic and climatic implications of fluvial archives. Earth-Science Reviews, v. 207, p. 103228, 2020.

BRIERLEY, G. J.; FRYIRS, K. A. Geomorphology and river management: applications of the river styles framework. Oxford: Blackwell Publishing, 2005. 398p.

CARVAlHO, A.; MAGAlHÃES JUNIOR, A. P.; OLIVEIRA, L. A. F. Considerações sobre a evolução geomorfológica e a dinâmica fluvial a partir da interpretação de perfis longitudinais e de índices morfométricos de afluentes do médio/baixo rio Paraopeba MG. In: SIMPÓSIO BRASILEIRO DE GEOGRAFIA FÍSICA APLICADA. 18., Fortaleza. Anais... Fortaleza: UFC, 2019. p. 1-13. 
CARVAlho, A.; MAGalhães JUNIOR, A. P.; OLIVEIRA, L. A. F. Controle litológico e dinâmica fluvial em unidades de relevo na bacia do Médio/Baixo Rio Paraopeba E Áreas Adjacentes, Minas Gerais. In: SIMPÓSIO BRASILEIRO DE GEOGRAFIA FÍSICA APLICADA. 18., Fortaleza. Anais... Fortaleza: UFC, 2019. p. 1-12.

CHAVES, A. O. O enxame de diques de anfibolito do Cráton do São Francisco meridional. Revista Brasileira de Geociências, v. 41, n. 3, p. 509-524, 2011.

CHRISTOFOLETTI, A. Geomorfologia. 2 ed. São Paulo: Edgard Blücher, 1980. 188p.

CHRISTOFOLETTI, A. Geomorfologia Fluvial. São Paulo: Edgar Blucher Ltda, 1981. 313p.

COBRAPE - CIA BRASILEIRA DE PROJETOS E EMPREENDIMENTOS. Plano Diretor de Recursos Hídricos do Rio Paraopeba. Revisão do Relatório do Diagnóstico da Bacia do Rio Paraopeba. 2018, 58p.

COPPE - INSTITUTO ALBERTO LUIZ COIMBRA DE PÓS-GRADUAÇÃO E PESQUISA DE ENGENHARIA. Projeto COPPE-22.265. Impactos ambientais da ruptura da barragem de rejeitos de brumadinho nos primeiros doze meses após o desastre: avaliação da qualidade de águas, de rejeitos, solo e sedimentos e da biota aquática e comunidades ripárias no Rio Paraopeba. Relatório final - Respostas aos comentários da Vale. Rio de Janeiro: Fundação Coppetec/ UFRJ. 17 de setembro de 2020, 1321p.

COTA, G. E. M.; ROSA, N. M. G.; ROMEIRO, C. E. MENDES, I. A. S.; MAGALHÃES JÚNIOR, A. P. M. Aspectos legais da segurança de barragens de rejeito de minério: implicações para a qualidade ambiental e usos múltiplos da água no Alto Rio das Velhas (MG). GEOgraphia, Niterói, v. 21, n. 45 , p. 32-46, 2019.

CPRM -SERVIÇO GEOLÓGICO DO BRASIL. Mapa geológico do estado de Minas Gerais. Relatório técnico metodológico de análise a ambiental $\mid 70$. Belo Horizonte: CPRM, 2003. Escala 1:1.000.000. Disponível em <http://rigeo.cprm.gov.br/xmlui/handle/doc/5016?show=full $>$. Acesso em: 26 ago. 2020.

CPRM - SERVIÇO GEOLÓGICO DO BRASIL. Boletim de monitoramento compartilhado do rio Paraopeba: Ruptura da Barragem do Complexo do Feijão em Brumadinho - MG. Boletim número 62. Belo Horizonte, Abr/2019, 22p.

CPRM - SERVIÇO GEOLÓGICO DO BRASIL. Monitoramento Especial Da Bacia do Rio Paraopeba Relatório IV: Monitoramento Hidrológico e Sedimentométrico. Belo Horizonte, Jul/2019 (2019a), 97p. Disponível em <http://www.cprm.gov.br/sace/index_rio_paraopeba.php>. Acesso em: 31 dez. 2020.

COPAM - CONSELHO ESTADUAL DE POLÍTICA AMBIENTAL (MINAS GERAIS); CERH CONSELHO ESTADUAL DE RECURSOS HÍDRICOS DO ESTADO DE MINAS GERAIS (Minas Gerais). Deliberação Normativa Conjunta COPAM/CERH-MG n ${ }^{\circ}$ 01, de 05 de maio de 2008. Dispõe sobre a classificação dos corpos de água e diretrizes ambientais para o seu enquadramento, bem como estabelece as condições e padrões de lançamento de efluentes, e dá outras providências. Minas Gerais, Belo Horizonte, 13 maio, 2008.

FRANÇA JUNIOR, P.; SOUZA, M. L. Tecnógeno em ambientes fluviais: noroeste do Paraná, Brasil. Quaternary and Environmental Geosciences, v. 05, n. 2, p. 45-52, 2014. 
FURNAS. Usina Retiro Baixo - 82 MW. Disponível em < https://www.furnas.com.br/subsecao/131/usina-retiro-baixo---82-mw?culture=pt $>$. Acesso em: 28 ago. 2020.

GOUDIE, A. Human influence in geomorphology. Geomorphology, 7, p. 37-59, 1993.

HOOKE, R. L. On the history of humans as geomorphic agents. Geology, v. 28, n. 9, p. 843-846, 2000.

HORTON, R. E. Erosional Development of Streams and their Drainage Basins: Hydrophysical Approach to Quantitative Morphology. Geological Society of America Bulletin, v. 56, n. 3, p. 275$370,1945$.

INSTITUTO BRASILEIRO DE GEOGRAFIA E ESTATÍSTICA - IBGE. Mapa de Unidades de Relevo do Brasil, escala 1:15.000.000, 2010.

INSTITUTO DE GEOCIÊNCIAS APLICADAS - IGA; SETEC - SECRETARIA DE ESTADO DE CIÊNCIA E TECNOLOGIA. Projeto RADAR - Minas Gerais. Mapa Geomorfológico. Belo Horizonte: IGA/SETEC, Folha Belo Horizonte, 1:500.000, 1977.

INSTITUTO GUAICUY - SOS Rio das Velhas. Projeto básico $\mathbf{n}^{\mathbf{0}}$ 003/2020: coleta e análise de amostras de água bruta superficial, sedimentos e solos em trechos da bacia rio Paraopeba e bacia do entorno do reservatório de Três Marias. Disponível em < https://guaicuy.org.br/transparencia/editais/>. Acesso em: 08 dez. 2020.

INSTITUTO MINEIRO DE GESTÃO DAS ÁGUAS - IGAM. Avaliação da qualidade das águas e sedimentos do Rio Paraopeba: acompanhamento da qualidade das águas do Rio Paraopeba após 1 ano do rompimento da barragem da Mina Córrego Feijão da Mineradora Vale/SA Brumadinho/MG / Instituto Mineiro de Gestão das Águas. Belo Horizonte: IGAM, 2020c. 66p.

INSTITUTO MINEIRO DE GESTÃO DAS ÁGUAS - IGAM. Caderno 1 Ano - Rompimento das barragens da Vale em Brumadinho. Belo Horizonte: SEMAD - MG, 2020b, 68p. Disponível em $<$ http://feam.br/recuperacao-ambiental-da-bacia-do-rio-paraopeba/-acoes-e-programas $>$. Acesso em 31 dez. 2020.

INSTITUTO MINEIRO DE GESTÃO DAS ÁGUAS - IGAM. Nota Técnica $\mathbf{n}^{\mathbf{0}}$ 5/IGAM/GEMOQ/2020, Processo $n^{0}$ 2240.01.0000428/2019-10. Belo Horizonte: SEMAD - MG, 2020a. Disponível em < http://feam.br/recuperacao-ambiental-da-bacia-do-rio-paraopeba/-acoes-eprogramas-de-recuperacao-ambiental-da-bacia-hidrografica-do-rio-paraopeba $>$. Acesso em: 30 dez. 2020.

INSTITUTO MINEIRO DE GESTÃO DAS ÁGUAS - IGAM. Informativo Especial de qualidade da água do Paraopeba - Série Histórica entre 2000 a 2018. Rompimento da Barragem da Mina Córrego do Feijão em Brumadinho. Belo Horizonte: GMHEC, 2019. Disponível em $<$ http://feam.br/recuperacao-ambiental-da-bacia-do-rio-paraopeba/-acoes-e-programas-derecuperacao-ambiental-da-bacia-hidrografica-do-rio-paraopeba>. Acesso em: 30 dez. 2020.

INSTITUTO MINEIRO DE GESTÃO DAS ÁGUAS - IGAM. Informativo Hidrometeorológico de acompanhamento do deslocamento da pluma no percurso do rio Paraopeba Informativo Especial - Rompimento da Barragem da Mina Córrego do Feijão em Brumadinho. Belo Horizonte: GMHEC, boletim $\mathrm{n}^{\circ} \quad 27, \quad 2019 \mathrm{a}$ Disponível em 
$<$ http://www.meioambiente.mg.gov.br/component/content/article/13-informativo/3749--informa>. Acesso em: 17 abr. 2021.

INSTITUTO MINEIRO DE GESTÃO DAS ÁGUAS - IGAM. Rejeitos da Barragem da Vale não atingiram o Rio São Francisco, 10/05/2019. Belo Horizonte: IGAM, Banco de Notícias, 2019b. Disponível em <http:/www.igam.mg.gov.br/banco-de-noticias/2100-rejeitos-da-barragem-da-valenao-atingiram-o-rio-sao-francisco>. Acesso em: 17 abr. 2021.

MEDEIROS, M. J. Avaliação da vazão referencial como critério de outorga dos direitos de usos das águas na Bacia do Rio Paraopeba. 2020. 176 f. Dissertação (Mestrado em Saneamento, Meio Ambiente e Recursos Hídricos) - Departamento de Engenharia Sanitária e Ambiental, Universidade Federal de Minas Gerais, Belo Horizonte, 2020.

MENDES, L. C.; FELIPPE, M. F. Alterações geomorfológicas de fundo de vale na Bacia do Rio do Carmo decorrentes do rompimento da barragem de Fundão (Minas Gerais, Brasil). Revista Caminhos de Geografia, Uberlândia, v. 20, n. 69, p. 237-252, 2019.

MILANEZ, B.; LOSEKANN, C. (Org.). Desastre no Vale do Rio Doce: Antecedentes, impactos e ações sobre a destruição. Rio de Janeiro: Folio Digital - Letra e Imagem, 2016. 437p.

MINISTÉRIO DA SAÚDE (BR). Secretaria de Vigilância em Saúde. Um ano do desastre da Vale: Organização e resposta do Ministério da Saúde. Boletim Epidemiológico. 2020 jan.; 51(n.esp.):135. Disponível em: http://www.saude.gov.br/boletins-epidemiologicos. Acesso em: 06 mar. 2021.

OLIVEIRA, A. M. S.; PELOGGIA, A. U. G. The Anthropocene and the Technogene: stratigraphic temporal implications of the geological action of humankind. Quaternary and Environmental Geosciences, v. 05, n. 2, p. 103-111, 2014.

PELOGGIA, A. U. G. A cidades, as vertentes e as várzeas: a transformação do relevo pela ação do homem no município de São Paulo. Revista do Departamento de Geografia, São Paulo, v. 16, p. 24-31, 2005.

REIS, M. O.; MOURA, A. C. M. B.; COTA, G. E. M.; MAGALHÃES JÚNIOR, A. P. Panorama dos rompimentos de barragens de rejeitos de minério no mundo. Caderno de Geografia, v. 30, n. 61, p. 368-390, 2020.

ROSGEN, D. L. A Classification of Natural Rivers. Catena, v. 22, p. 169-199, 1994.

SISEMA. Infraestrutura de Dados Espaciais do Sistema Estadual de Meio Ambiente e Recursos Hídricos (IDE-Sisema). 2020. Disponível em <http://idesisema.meioambiente.mg.gov.br/>. Acesso em: 28 ago. 2020.

SUMMERFIELD, M. A. Global Geomorphology. Burnt Mill: Longman Scientific e Technical, 1991. 537p.

THOMPSON, F.; OLIVEIRA, B. C.; CORDEIRO, M. C.; MASI, B. P.; RANGEL, T. P.; PAZ, P.; FREITAS, T.; LOPES, G.; SILVA, B. S.; CABRAL, A. S.; SOARES, M.; LACERDA, D.; VERGILIO, C. S.; LOPES-FERREIRA, M.; LIMA, C.; THOMPSON, C.; REZENDE, C. E. Severe impacts of the Brumadinho dam failure (Minas Gerais, Brazil) on the water quality of the Paraopeba River. Sci. Total Environ., n. 705, p. 135914, 2020. 
VERGILIO, C. S.; LACERDA, D.; OLIVEIRA, B. C. V.; SARTORI, E.; CAMPOS, G. M.; PEREIRA, A. L. S.; AGUIAR, D. B.; SOUZA, T. S.; ALMEIDA, M. G.; THOMPSON, F.; REZENDE, C. E. Metal concentrations and biological effects from one of the largest mining disasters in the world. Brumadinho, Minas Gerais, Brazil, Scientific Reports, v. 10, n. 5936, 2020.

Trabalho enviado em $29 / 04 / 2021$

Trabalho aceito em 07/05/21 